\title{
UYUŞTURUCU VEYA UYARICI MADDE SUÇLARINDA KİŞISEL KULLANIM AMACININ BELİRLENMESİ (TCK m. 188/3-TCK m. 191)

\author{
(Araştırma Makalesi)
}

DOI: https://doi.org/10.33717/deuhfd.998169

\section{Dr. Ziya KOÇ*}

\section{$\ddot{O ̈ z}$}

Uyuşturucu madde imal ve ticareti suçu TCK m. 188'de düzenlenmiştir. Kullanmak için uyuşturucu maddenin satın alınması, kabul edilmesi, bulundurulması ise TCK m. 191'de yaptırıma bağlanmıştır. Kullanma dışındaki diğer seçimlik hareketler her iki suç tipinde aynıdır. Bu durum, fiilin inceleme konusu suç tiplerinden hangisini oluşturduğu hususunda tereddütlere sebep olmaktadır.

Uyuşturucu veya uyarıcı maddenin satın alınmast, kabul edilmesi veya bulundurulmasinin hangi amaçla gerçekleştiğinin belirlenmesi, TCK m. 188/3 ve TCK m. 191'de düzenlenen suç tipleri bakımından önemlidir. Suçun manevi unsuru bağlamında yapılacak bu değerlendirme, niteliği itibarıyla, failin iç dünyasina ait bir meseledir.

Failin kullanma veya bunun dışında bir maksatla hareket edip etmediği ile ilgili Yargıtay'ın kabul ettiği bazı kriterler vardır. Yargıtay meseleye çok yönlü bir biçimde yaklaşmakta ve failin kastını belirlemeye çalışmaktadır. Esasen bu yaklaşım yerindedir. Ancak, uygulamada bazı sorunların yaşandı̆̆ görülmektedir. Söz gelimi, madde miktarı problemli alanların başında gelmektedir. Bu sebeple tek bir kriter ile hareket edilmemesi, failin kastının somut olayın özelliklerine göre dayanak noktaları da gösterilmek suretiyle tespit edilmesi gerekir.

\section{Anahtar Kelimeler}

Uyuşturucu, Uyarıcı madde, Kullanma, Ticaret, Ceza hukuku

Adalet Bakanlı̆̆ı, Adana Ağır Ceza Mahkemesi Başkanı, Adana (ziyakoc@yahoo.com), ORCID: 0000-0002-0160-1997 (Geliş Tarihi: 07.07.2021-Kabul Tarihi: 21.08.2021) 


\title{
DETERMINING THE PURPOSE OF PERSONAL CONSUMPTION IN DRUGS OR STIMULATING SUBSTANCES (TPC Art. 188/3 - TPC Art. 191)
}

\author{
(Research Article)
}

\begin{abstract}
Production and trade of narcotics and psychotrophic subtances is a crime and that is regulated in article 188 of Turkish Penal Code (TPC). Purchase, receipt or possession of narcotics or psychotropic substances for personal use is also punished under article 191 of TPC. Except of use other acts are the same in both types of crime. This situation causes hesitations about which type of crime the act constitutes.

It is important to determine the purpose for which the drug or stimulant was purchased, accepted, or owned (article of 188/3 or 191 Turkish Penal Code). This assessment to be made in terms of the mens rea element of the crime that belongs to the inner world of the perpetrator. But it is possible to determine with which intention the perpetrator acted from his outward reflected movements.

There are some criteria accepted by the Supreme Court regarding whether the perpetrator acts with a purpose of using it or not. The Supreme Court prefers to approach the issue in a versatile manner and tries to determine the intention of the perpetrator. Essentially this approach is true. But it seems that there are some problems in practice. For example, the amount of matter is one of the problematic areas. For this reason, it should not be acted upon by a single criterion, and the aim of the perpetrator should be determined according to the characteristics of the specific event.
\end{abstract}

\section{Keywords}

Drug, Stimulant, Drug use, Drug trade, Criminal law 


\section{GİRIŞ}

Uyuşturucu veya uyarıcı madde kullanımı günümüzde halk sağlığını ciddi bir biçimde tehdit etmektedir. Karşılaştırmalı hukukta uyuşturucu madde kullanımının suç olmaktan çıkarılmasına yönelik eğilimler bulunmakla beraber, yaygın kullanımın engellenmesi amaciyla sınırlayıcı politikaların uygulandığ 1 görülmektedir. Nitekim hukukumuz bakımından uyuşturucu maddenin kullanılması TCK'da suç olarak düzenlenmiştir.

Uyuşturucu madde kullanımının yaygınlaşması ve bu konuda benimsenen katı tutumlar beraberinde başka sorunları da getirmektedir. Nihayetinde, bir uyuşturucu madde kullanıcısının bulunduğu durumlarda bir de bu maddeyi temin eden taraf bulunmaktadır. Bu husus, bilhassa uyuşturucu veya uyarıcı maddenin miktar itibarıyla fazla olduğu hallerde karışıklığa sebep olmaktadır. TCK'nın 191. maddesinde düzenlenen suç tipinde sayılan hareketler, kullanma dışında TCK m. 188/3'te düzenlenen hareketler ile aynıdır. $\mathrm{Bu}$ nedenle, uyuşturucu madde üzerindeki fiili hâkimiyetin hangi suç tipi uyarınca değerlendirileceği meselesi önemlidir.

Uyuşturucu madde üzerindeki fiili hâkimiyetin hangi amaçla bulundurulduğunun tespiti, niteliği gereği failin iç dünyası ile, başka bir deyişle, suçun sübjektif unsuru ile alakalıdır. O halde, sübjektif bir meselenin tespiti, harici olgular çerçevesinde ele alınmalıdır. Karşılaştırmalı hukukta meselenin çözümü ile ilgili farklı yöntemler bulunmaktadır. Hukukumuz bakımından da Yargıtay'ın belirlediği bazı kriterler vardır.

Uygulama, Yargitay içtihatları çerçevesinde şekillenmektedir. Belirtmek gerekir ki Yargıtay'ın konu ile ilgili içtihatları büyük ölçüde yerleşmiş olmasına rağmen, uygulamada tereddütlerin yaşandığ hallerde uyuşturucu veya uyarıcı maddenin kullanmak için satın alındığı, kabul edildiği veya bulundurulduğu ya da ticari amaçla bu fiillerin gerçekleştirildiği her olayda kolaylıkla ortaya konulamamaktadır. Yargıtay'ın suçun manevi unsurunun belirlenmesi, ticaret veya kullanma amacının tespit edilmesi için aradığı kriterlerin neler olduğunu somut örnekler üzerinden ortaya koymakta yarar vardır.

Çalışmamızda, TCK'nın 188/3 ve 191. maddeleri bakımından bir değerlendirmede bulunulacaktır. Öncelikle bu maddelerde düzenlenen suçlar hakkında genel açıklamalara yer verilecektir. Karşılaştırmalı hukukta meselenin ne şekilde ele alındığ 1 çeşitli ülkelerin mevzuat ve uygulamalarından örneklerle ortaya konulduktan sonra fiilin hangi amaçla işlendiğine yönelik Yargıtay tarafından benimsenen kriterler ele alınacak, son olarak buna ilişkin görüş ve düşüncelerimiz açıklanacaktır. 


\section{UYUŞTURUCU VEYA UYARICI MADDE SUÇLARINA İLIŞKİN TEMEL AÇIKLAMALAR}

\section{A. Kavram-Tanım}

TCK’nın özel hükümler kitabının üçüncü kısmı "Topluma Karşı Suçlar" başlığını taşımaktadır. Bu kısım içerisinde üçüncü bölümde "Kamunun Sağlığına Karşı Suçlar" düzenlenmiştir ${ }^{1}$. Uyuşturucu madde suçları bu bölümde yer almaktadır (TCK m. 188 ile 192). Bununla birlikte, 2313 sayılı Uyuşturucu Maddelerin Murakabesi Hakkında Kanun ve 3298 sayılı Uyuşturucu Maddelerle İlgili Kanun olmak üzere diğer kanunlarda da uyuşturucu veya uyarıcı madde suçlarına ilişsin hükümler bulunmaktadır.

Ülkemizin tarafı olduğu "1961 tarihli Uyuşturucu Maddeler Tek Sözleşmesi”, “1971 tarihli Psikotrop Maddeler Sözleşmesi” ve "1988 tarihli Uyuşturucu ve Psikotrop Maddelerin Kaçakçıllı̆ına Karşı Birleşmiş Milletler Sözleşmesi” de iç hukukumuzun birer parçasıdır. Anayasa'nın 90. maddesi çerçevesinde usulüne göre yürürlüğe konulmuş Milletlerarası andlaşmalar kanun hükmündedir (Anayasa, m. 90/5).

\footnotetext{
Uyuşturucu veya uyarıcı madde suçları için bkz. Yurtcan, Erdener: Yargıtay Kararları Işı̆̆ında Uyuşturucu Suçları, 6. Baskı, Ankara 2021, s. 58 vd; Tezcan, Durmuş/Erdem, M. Ruhan/Önok, Murat: Teorik ve Pratik Ceza Özel Hukuku, 18. Baskı, Ankara 2020, s. 983 vd; Bayraktar, Köksal vd., Özel Ceza Hukuku, Cilt: V, İstanbul 2019, s. 314 vd.; Gökcen, Ahmet: "Türk Ceza Kanununda Uyuşturucu Madde Suçlarına Genel Bakış”, Uyuşturucu Madde Bağımlılığıyla Mücadele ve Ceza Hukuku, Doğuş Üniversitesi Hukuk Fakültesi Panel (9 Mayıs 2011), Editör: Murat Balc1, Ankara 2011, s. 29 vd; Özbek, Veli Özer/Doğan, Koray/Bacaksız, Pınar: Türk Ceza Hukuku, Özel Hükümler, 15. Bask1, Ankara 2020, s. 773; Arslan, Çetin: Yargıtay'ın "Uyuşturucu ve Uyarıcı Madde Suçları”na İlişkin Kimi Güncel Kararları ve Bunların Değerlendirilmesi”, Uyuşturucu Madde Suçlarına Genel Bakış, Uyuşturucu Madde Bağımlılığıyla Mücadele ve Ceza Hukuku, Doğuş Üniversitesi Hukuk Fakültesi Panel (9 Mayıs 2011), Editör: Murat Balc1, Ankara 2011, s. 83 vd; Yaşar, Yusuf: Uyuşturucu ve Uyarıcı Madde İmal ve Ticareti Suçları, 3. Baskı, Ankara 2019, s. 27 vd; Sevdim, Ali Erdim: Uyuşturucu veya Uyarıcı Madde İmal ve Ticareti Suçu, Ankara 2014, s. 23 vd; Elmas, Birsen: Uyuşturucu ve Uyarıcı Madde Suçları, 4. Baskı, Ankara 2020, s. 27 vd; Kıdıl, Fahrettin: Türk Ceza Hukukunda Uyuşturucu ve Uyarıcı Madde İmal ve Ticareti Suçları, Ankara 2020, s. 17 vd; Aksüt, Ertekin, Uyuşturucu veya Uyarıcı Madde İmal ve Ticareti Suçları, Ankara 2020, s. 21 vd; Bıkmaz, Raif: "Uyuşturucu ve Uyarıcı Madde Ticareti Suçları", Fasikül, Şubat 2019, Sayı:111, s. 579 vd; Meydan, Uğur: "Uyuşturucu Madde Ticareti Suçunda Madde Miktarının Önemi”, TAAD, Y1l: 10, Say1: 37, Ocak 2019, s. 321 vd; Çetin, Hamza: "Kullanmak İçin Uyuşturucu veya Uyarıcı Madde Satın Almak, Kabul Etmek, Bulundurmak ya da Uyuşturucu veya Uyarıcı Madde Kullanmak Suçu (TCK m. 191), AÜHFD, 65(4) 2016, s. 1353 vd”; Öner, Mehmet Zülfü: “Türk Ceza Kanunu'nda Uyuşturucu Madde İmal, İthal ve İhraç Suçları”, TBB Dergisi, Sayı: 88, 2010, s. 106 vd.
} 
TCK m. 188'de uyuşturucu veya uyarıcı madde imal ve ticareti, 190. maddede uyuşturucu veya uyarıcı madde kullanılmasını kolaylaştırma, 191. maddede kullanmak için uyuşturucu veya uyarıcı madde satın almak, kabul etmek veya bulundurmak ya da uyuşturucu veya uyarıcı madde kullanma fiilleri yaptırıma bağlanmıştır. 189. maddede tüzel kişiler hakkında güvenlik tedbiri uygulanmasına, 192. maddede ise etkin pişmanlık hükümlerine yer verilmiştir.

TCK'da uyuşturucu veya uyarıcı maddelerin bir tanımına rastlanmamaktadır. Esasen suçun konusunun kanun koyucu tarafından belirlenmesinin kişi özgürlüğü açısından daha güvenceli olduğu iddia edilebilir². Ancak, kimya ve eczacılık alanında görülen değişimlerin sürati karşısında kazuistik bir düzenleme yapılmaması yerindedir. Aksi takdirde, Kanunda sürekli değişikliklere gitmek gerekecektir. Kanunların soyut oluşu ilkesi gereğince bir tanımdan kaçınılması yerindedir. Nitekim bu durum TCK m. 188'in gerekçesinde şu şekilde vurgulanmıştır: “(...)Burada uyuşturucu veya uyarıcı maddelerin nelerden ibaret bulunduğu tanımlanmadı̆̆ gibi, bunların teker teker gösterilmesi yoluna da gidilmemiştir. Bunun nedeni, uyuşturucu veya uyarıcı maddelerin ve ayn etkiyi yapan ilâç ve sentetiklerin kötüye kullanılmalarının yaptırım altına alınarak güçlü bir sosyal savunmanın sağlanmasidir".

Sözlük anlamı itibarıyla uyuşturucu, "uyuşturma özelliği olan, uyuşturan (madde), narkotik"3 veya "hareketten, gereği gibi düşünmekten alıkoyan" "4 anlamlarına gelmektedir. Bu tanımlardan anlaşılacağı üzere uyuşturucu maddenin temel özelliği kişiyi uyuşturarak düşünme yeteneğinden alıkoymasidır.

Bazı metinlerde uyuşturucu maddenin tanımına yer verilmiştir. Dünya Sağlık Örgütü'ne göre bitkisel veya sentetik kökenli olup, merkezi sinir sistemini etkileyerek fiziksel ve/veya ruhsal bağımlılık hallerine yol açan, bazı hallerde kullanmanın devamı üzerine dozajı artırma ihtiyacının duyulmasına, bazı hallerde ise aynı kişinin değişik uyuşturucu madde kullanmasina neden olan, tutku yaratan maddeler uyuşturucu maddelerdir ${ }^{5}$.

Bir başka metindeki tanıma göre uyuşturucu madde: "Belirli dozda alındığ zaman, kişinin sinir sistemi üzerinde etki ederek; akli, fiziki ve

Soyaslan, Doğan: Ceza Hukuku, Özel Hükümler, 12. Bask1, Ankara 2018, s. 489.

www.sozluk.gov.tr erişim tarihi 23.08.2021.

www.sozluk.gov.tr erişim tarihi 23.08.2021.

Erman, Sahir/Özek, Çetin: Ceza Hukuku Özel Bölüm, Kamunun Selametine Karşı Suçlar (TCK m. 369-413), s. 257. 
psikolojik dengesini bozan, fert ve toplum açısından iktisadi ve sosyal çöküntü meydana getiren, bağımlılık yapan, kanunların kullanılmasını, bulundurulmasını ve ticaretini yasakladı̆̆ maddeler" ${ }^{\prime}$ şeklinde tanımlanmıştır.

Ceza hukuku doktrininde uyuşturucu ve uyarıcı maddelerin, bilimsel kanıtlara göre bağımlılık oluşturan, narkotik etkileri sebebiyle doğrudan veya dolaylı olarak insan sağlığına zarar veren; uyuşturucu veya uyarıcı madde üretiminde kullanılan maddeler olduğu ifade edilmiştir ${ }^{7}$.

Bir başka görüşe göre bir maddenin uyuşturucu veya uyarıcı madde sayılıp sayılmayacağı, o maddenin uyarıc1, keyif verici, hayal doğurucu, tahrik ve sarhoş edici olup olmadığına, insanın irade ve muhakemesini ortadan kaldırıp kaldırmadığına bağlı olduğu ifade edilmiştir ${ }^{8}$.

\section{B. Korunan Hukuki Değer}

TCK m. 188/1'de uyuşturucu veya uyarıcı maddeleri ruhsatsız veya ruhsata aykırı olarak imal, ithal veya ihraç hareketleri yaptırıma bağlanmıştır. Aynı maddenin 3. fikrasında, uyuşturucu veya uyarıcı maddeleri ruhsatsız veya ruhsata aykırı olarak ülke içinde satma, satışa arz etme, başkalarına verme, sevk etme, nakletme, depolama, satın alma, kabul etme, bulundurma; 7. fikrada ise uyuşturucu veya uyarıcı madde üretiminde kullanılan maddeyi temin hareketleri cezalandırılmaktadır.

TCK'nın 188. maddesi, kamunun sağlığına karşı suçlar arasında düzenlenmiştir ${ }^{9}$. Bu sebeple, korunan hukuki değer öncelikle kamunun sağl1$\breve{g} 1 d{ }^{10}{ }^{10}$. Bununla birlikte, uyuşturucu veya uyarıcı madde imal ve ticareti suçları sadece belli bir ülke halkını değil, bütün toplumu ve hatta tüm insan-

6 Başbakanlık Ulusal Uyuşturucu Politika ve Strateji Belgesi, bkz. Yokuş Sevük, Handan: Türk Ceza Hukuku, Özel Hükümler, 2. Bask1, Ankara 2019, s. 347.

7 Körner, Herald Hans/Patzak, Jörn/Volkmer, Mathias: Betäubungmittelgesetz, 9. Bask1, München 2019, §§ 29, Rn. 1, erişim için www.beck-online.de erişim tarihi 30.01.2021; Oğlakçıŏlu, Mustafa Temmuz: Münchener Kommentar zum StGB, 3. Bask1, München 2017, § 29, Rn. 9.

8 Soyaslan, s. 490.

9 Yurtcan, s. 58; Bayraktar vd., s. 321.

10 Özbek/Doğan/Bacaksız, s. 775. Bu suçlar aslında toplum sağlığı için tehlike arz eden suçlardır. Somut olayda bir tehlike veya zararın somut olarak bir şekilde gerçekleşmesi gerekmez. Esasen, normatif bir tehlike suçun oluşması için yeterlidir. Bu anlamda Kanun'un toplumsal yapı için uyuşturucu veya uyarıcı maddelerin tehlikeli olduğunu öngördüğü anlaşılmaktadır. Yenisey, Feridun: "Uyuşturucu Maddeler Sorunun Ceza Hukuku Yönü”, Dicle Üniversitesi Hukuk Fakültesi Dergisi, Cilt:1, Sayı:1, Ekim 1983, s. 179. 
lığ1 tehdit eden suçlardır ${ }^{11}$. Bu nedenle, karşılaştırmalı hukukta uyuşturucu madde suçları tüm insanlığın sağlığına karşı işlenmiş suçlar olarak kabul edilmektedir $^{12}$. Halk sağllğının korunmasına ek olarak, ilgili suçlardan bireysel olarak etkilenen kişilerin yaşamının ve sağlığının korunması da bir diğer amaçtır ${ }^{13}$. Nihayetinde, uyuşturucu madde suçlarının birden çok hukuki değeri koruduğu söylenebiliir ${ }^{14}$. Suç ile korunan bu değerler aynı zamanda kanun koyucunun kabul ettiği cezai yaptırımların ve sınırlamaların meşruiyetini sağlamada bağlantı noktasını oluşturmaktadır ${ }^{15}$.

TCK m. 191 yukarıda izah edilen hukuki değerleri aynen korumaktadır. TCK m. 191/3'te uyuşturucu veya uyarıcı madde kullanan kişiler hakkında denetimli serbestlik tedbiri ile gerek görüldüğü takdirde bu kişilerin tedaviye tabi tutulmaları öngörülmektedir. Bu düzenleme ile bireylerin sağlığına özel bir önem verildiği anlaşılmaktadır ${ }^{16}$.

Uyuşturucu maddeler, tıbbi amaçlarla kullanıldığından toplum sağlığı açısından önemlidir. Bireylerin tıbbi hizmetlerden faydalanmasında uyuşturucu maddelere her daim ihtiyaç vardır. Ağrı ve 1stırabın dindirilmesinde kullanılabileceği gibi bu maddelerin kötüye kullanılmaları da mümkündür. Toplumun bu zararlı etkilerden korunması ve suç örgütlerinin finansal açıdan güçlenmelerinin önlenmesi de bir diğer sebeptir ${ }^{17}$. Bunun yanında,

11 Schäfer, Gerhard/Sander, Günther M./Von Gemmeren, Gerhard: Praxis der Strafzumessung, 6. Bask1, München 2017, BtMG, Rn. 1749.

12 Tezcan/Erdem/Önok, s. 984.

13 Doktrinde, bireyin sağlığının korunmasının fiilin suç olarak düzenlenmesinin gerekçesi olamayacağı, çünkü kişinin kendisine zarar vermesinin cezalandırılmadığı belirtilmiştir. Uyuşturucu suçlarının bireylerin sağlığını korumaktan ziyade, halk sağlığını koruduğu ifade edilmiştir. Esasen, uyuşturucu madde kullanımının yasaklanmasının gerekçesinin halkın kontrol edilemeyen uyuşturucu maddelerin varlığı sebebiyle çok sayıda üyesinin kendilerine zarar vermesi ve böylece sağlık sistemi için yüksek maliyetlere yol açması endişesi olduğu ileri sürülmüştür. Doktrinde bu görüş eleştirilmiştir: Bu düşüncenin tartışmaya açık olduğu, benzer bakış açısıyla alkol tüketiminin de yasaklanması gerektiği belirtilmiştir. Cezai sorumluluğun gerekçesinin, şahsi tüketim için de olsa, bu maddelerin her an satışa sunulması, başkalarına zarar verilmesi olasıllığı olduğu; failin sahip olduğu uyuşturucu maddelerin her halde halk sağllğ için bir tehlike oluşturduğu ifade edilmiştir. Heinrich, Bernd/Van Bergen, Nicolas: Grundzüge des deutschen Betäubungsmittelstrafrechts und seine Entkriminalisierungstendenzen, Juristische Arbeitsblätter, 2019, s. 323, www.beck-online.beck.de erişim tarihi 15.05.2021.

14 Schäfer/Sander/Von Gemmeren, BtMG, Rn. 1749.

15 Oğlakçıŏlu, $\S 29$, Rn. 2.

16 Yokuş Sevük, s. 402.

17 Bayraktar vd., s. 317; Oğlakçıŏ̆lu, § 29, Rn. 1. 
uyuşturucu veya uyarıcı maddelerin imal ve ticareti suçları ile kültürel ve toplumsal düzenin korunduğu da söylenebilirr ${ }^{18}$.

\section{Suçun Unsurları}

Uyuşturucu veya uyarıcı madde imal ve ticareti suçları, doktrinde ifade edildiği üzere, uyuşturucu veya uyarıcı madde kullanımına ön gelen suçlardandır ${ }^{19}$. Bu nedenle suç tipleri arasında sıkı bağlantı vardır. Bu bölüm altında her iki suç tipinin unsurlarına ilişkin genel açıklamalara yer verilecektir.

TCK m. 188/3 ve TCK m. 191 bakımından suçun faili bir özellik göstermez; fail herkes olabilir ${ }^{20}$. Failin tabip, diş tabibi, eczacı, kimyager, veteriner, sağlık memuru, laborant, ebe, hemşire, diş teknisyeni, hastabakıcı, sağlık hizmeti veren, kimyacılıkla veya ecza ticareti ile iştigal eden kişi olmas1; yani failin Kanun'da belirtilen meslek gruplarından birine mensup olması cezayı ağırlaştıran nedenler arasındadır (TCK m. 188/8).

TCK m. 188/3 ve TCK m. 191'de düzenlenen suç tipleri bakımından suçun mağduru kamudur ${ }^{21}$. Ancak uyuşturucu veya uyarıcı maddenin ülke içinde ticareti suçunda, uyuşturucu veya uyarıcı maddenin verildiği veya satıldığ kişinin çocuk olması hali cezayı ağırlaştıran bir nitelikli haldir (TCK m. 188/3-2. cümle).

Uyuşturucu veya madde ticareti ve kullanılması suçlarında, suçun konusu, uyuşturucu veya uyarıcı maddelerdir ${ }^{22}$. Uyuşturucu veya uyarıcı maddeler, doktrinde doğal nitelikli ve sentetik uyuşturucu veya uyarıcı maddeler olarak ikiye ayrılmaktadır. Doğal nitelikli uyuşturucu veya uyarıcı maddeler afyon, morfin, eroin, esrar, kokain, crack, marihuana; sentetik uyuşturucu veya uyarıcı maddeler depresantlar (yatıştırıcılar), hallüsinojenler (hayal gördürücüler), simulantlar (uyarıcılar), uçucu ve çözücü maddelerdir ${ }^{23}$.

Uyuşturucu maddelerin bir tanımına rastlanmamakla beraber, bu maddelerin nasıl tespit edileceği meselesi önemlidir. Ele geçirilen maddenin

\footnotetext{
18 Bayraktar vd., s. 322.

19 Bayraktar vd., s. 323.

$20 \quad$ Bayraktar vd., s. 327.

$21 \quad$ Bayraktar vd., s. 327.

22 Doktrinde bu durum eleştirilmiştir. Kanun'da uyuşturucu veya uyarıcı madde ya da bunların üretiminde kullanılan maddelerden söz edildiği, ancak bunların neler olduğuna açıklık getirilmediği, söz konusu maddelerin neler olduğunun sadece kanuni düzenlemeler ile belirlenebileceği, idarenin düzenleyici işlemleri ile belirlenmesinin mümkün olmadığı ifade edilmiştir. Görüşler için bkz. Özbek/Doğan/Bacaksız, s. 775.

23 Konu ile ilgili detaylı tasnif için bkz. Özbek/Doğan/Bacaksız, s. 777-779.
} 
uyuşturucu veya uyarıcı madde olup olmadığı bilirkişi raporu ile belirlenmelidir. Esasen, bu konuda yetkili yer Adli Tip Kurumu'dur ${ }^{24}$. Yargitay kararlarında vurgulandığı üzere bu tespit suçun niteliğini etkilemektedir ${ }^{25}$.

Suçun konusunun eroin, kokain, morfin, sentetik kannabinoid ve türevleri veya bazmorfin olmasi halinde TCK m. 188/4-a uyarınca haksızlık içeriğinin fazlalığı sebebiyle ceza ağırlaştırılmaktadır ${ }^{26}$. Üretimi resmî makamların iznine veya satışı yetkili tabip tarafından düzenlenen reçeteye bağlı olan ve uyuşturucu veya uyarıcı madde etkisi doğuran her türlü maddelerin suçun konusunu oluşturması halinde ise TCK m. 188/6 uyarınca TCK m. $188 / 1$. ve 3 . fikralar gereğince hükmedilecek cezadan indirim yapılması öngörülmüştür.

TCK m. $188^{\prime}$ de uyuşturucu veya uyarıcı madde imal, ithal ve ticareti suçu düzenlenmiştir. TCK m. 188/1 bakımından suçun maddi unsurunu oluşturan hareketler imal, ithal veya ihraçtır. TCK m. 188/3'teki düzenlemeye göre bu hareketler satma, satışa sunma, başkalarına verme, nakletme, sevketme, depolama, satın alma, kabul etme veya bulundurmadır ${ }^{27}$.

24 Bayraktar vd., s. 330.

25 Yurtcan, s. 20; "sanığa atılı uyuşturucu madde ticareti yapma suçunun sübutu bakımından, tanık S.'a sattığı sabit olan maddenin uyuşturucu veya uyarıcı madde olup olmad1ğına ilişkin uzmanlık raporu bulunup bulunmadığının araştırılması, bulunmadığının tespiti hâlinde ise bu maddenin niteliğine ilişkin uzman bir kurum ya da kuruluştan rapor alınarak, sonucuna göre sanığın hukuki durumunun değerlendirilmesi gerekirken, eksik araştırmayla hüküm kurulmasının isabetsiz olduğu kabul edilmelidir”. Yargitay CGK, 16.05.2019, 20-732/439 UYAP.

26 Yargıtay bir kararında afyon sakızının TCK m. 188/4 kapsamında olmadığına karar vermiştir. Karar için bkz: "Erzurum Kriminal Polis Laboratuvarı Müdürlüğü'nün 21/08/2015 tarihli raporunda, suç konusu maddenin "afyon sakızı" olduğunun belirtilmesi karşısında; afyon sakızının "ham afyon” olduğu, 3298 sayılı Uyuşturucu Maddelerle İlgili Kanun'un 4. maddesinin 1. fikrasında “ham afyon, hazırlanmış afyon, tıbbî afyon ve bunların müstahzarları Türk Ceza Kanunu'nun uygulanmasında uyuşturucu maddelerden sayılır" hükmünün öngörüldüğü; ham afyonun TCK'nın 188. maddesinin 1 ve 3. fikraları kapsamında "uyuşturucu madde" olmasına rağmen, aynı maddenin 4. fikrası kapsamına girmediği ve bu konuda ham afyonun içerdiği etken maddenin dikkate alınamayacağı gözetilmeden; sözü edilen raporda suç konusu maddenin "morfin”" içerdiğinin belirtilmesine dayanılarak sanığın cezasının TCK'nın 188. maddesinin 4. fikrası uyarınca artırılması...". Yargitay 10. CD, 16/02/2016, 5778/433 UYAP.

27 "...uyuş̧urucu veya uyarıcı madde ticaretine ilişkin çeşitli fiiller, ayrı bir suç olarak tanımlanmıştır. Buna göre, uyuşturucu veya uyarıcı maddelerin ruhsatsız veya ruhsata aykırı olarak ülke içinde satışı, satışa arzı, başkalarına verilmesi, nakli, depolanması ya da kazanç amacıyla satın alınması, kabul edilmesi veya bulundurulması, bir ve ikinci fikralara göre ayrı bir suç oluşturmaktadır. Fıkradaki suçun oluşabilmesi için maddede belirtilen seçimlik hareketlerden herhangi birisinin yapılmış olması gerekir...". Yargıtay CGK, 21.05.2019, 10-343/445 UYAP. 
Ticaretin söz konusu olduğu durumlarda uyuşturucu veya uyarıcı maddenin satışının mümkün kılınması ve gerçekleştirilmesi yönünde bir çaba sarf edilmesi söz konusudur. Ticaret, niteliği gereği bir iradenin dışa vurumu olup, satış iradesinin bir tezahürü olarak kazanç sağlama niyetinin ortaya konulmasi yeterlidir ${ }^{28}$. Bu sebepledir ki teşebbüs mahiyetindeki birçok davranış tamamlanmış suç gibi cezalandırılmaktadır. Her somut olayda failin ticari amaçla fiilî hâkimiyetinde bulundurduğu uyuşturucu maddeyi satması ve bundan bir menfaat temin etmesi aranmamaktadır ${ }^{29}$. Öte yandan uyuşturucu veya uyarıcı madde ticaretinde kazancın mutlaka para ile ifade edilen bir menfaat olması gerekmez. Cinsel ilişki karşıllğında uyuşturucu madde temin edilmesi de ticaret kapsamındadır ${ }^{30}$.

TCK m. 188/1 uyarınca imal etmek, uyuşturucu veya uyarıcı maddenin üretilmesidir $^{31}$. Doğal veya sentetik bir hammaddenin değişik yöntemlerle işlenerek, hammaddeden tamamen ayrılabilecek nitelikte bir uyuşturucu veya uyarıcı maddenin ortaya çıkarılmasıdır. Bu anlamda uyuşturucu veya uyarıcı maddenin içeriğinde değişiklik yapmayan veya maddenin doğal niteliğini korumak amacıyla yapılan işlemler imal olarak değerlendirilemez ${ }^{32}$.

İthal etmek, "uyuşturucu maddelerin bir ülkeden başka bir ülkeye veya aynı ülkenin bir bölgesinden diğer bölgesine nakledilmesi" olarak tanımlanmıştır (1961 Tek Sözleşmesi m. 1). Bir uyuşturucu veya uyarıcı maddenin ruhsatsız veya ruhsata aykırı olarak, başka bir ülkeden Türkiye'ye sokulması halinde ithalden bahsedilebilir ${ }^{33}$. İhraç ise ithal etmenin aksine Türkiye sınırları dâhilinden başka bir ülkeye ruhsatsız veya ruhsata aykırı olarak uyuşturucu veya uyarıcı madde nakledilmesidir. İhraç etmede uyuşturucu veya uyarıcı madde Türkiye'nin gerçek sınırlarının dışına ruhsatsız veya ruhsata aykırı bir şekilde çıkarılmaktadır ${ }^{34}$.

28 Körner/Patzak/Volkmer, $\S \S 29$, Rn. 59. Alman hukukunda, uyuşturucu madde ticareti yalnızca uyuşturucu veya uyarıcı maddelerin satın alınmasına ve alıcılara sunulmasına doğrudan hizmet eden fiilleri değil, aynı zamanda satış görüşmelerini de kapsar. Satıcı, potansiyel alıcı ile satış yapmak için bağlayıcı ve ciddi bir teklif sunduğunda diğer unsurların da gerçekleşmesi halinde uyuşturucu madde ticareti tamamlanmış olur. BGH, Beschl. v. 17.6.2020 - 1 StR 110/20 (LG Tübingen), NStZ 2021, s. 53, www.beckbeck.online.de erişim tarihi 15.05.2021.

Oğlakçıı̆̆lu, $\S 29$, Rn. 82 .

Körner/Patzak/Volkmer, §§ 29, Rn. 103.

Yurtcan, s. 20.

Özbek/Doğan/Bacaksız, s. 781.

Uyuşturucu veya uyarıcı maddelerin ruhsata tabi olmakla birlikte kalite, miktar, türevleri açısından hukuka aykırı olarak üretimi, ithali ve ihracı da suç kabul edilmektedir. Soyaslan, s. 491.

34 Tezcan/Erdem/Önok, s. 988. 
TCK m. 188/3'te düzenlenen seçimlik hareketlerden ilki satmaktır. Satmaktan kastedilen uyuşturucu veya uyarıcı maddenin bedeli karşılığında başka birine devredilmesidir. Satma hareketi ile uyuşturucu veya uyarıcı madde alıcının hâkimiyet alanına sokulmaktadır. Satışa arz etme ise, uyuşturucu veya uyarıcı maddenin bir bedel karşılığında bir başkasına devredilmek üzere hazırlanmasıdır. Satışa arz, alıcı ile satıcının satım konusu olan uyuşturucu veya uyarıcı madde ile satım bedeli üzerinde anlaşmasını ve bu anlaşmanın karşılığ 1 olan edimlerin yerine getirilmesinden yani satıştan önceki aşamayı ifade etmektedir ${ }^{35}$. Mühim olan ticaret amacıyla uyuşturucu veya uyarıcı maddenin alınıp satılmasıdır. Paranın ödenip ödenmemesi veya eksik ödenmesinin bir önemi yoktur ${ }^{36}$. Belirtmek gerekir ki uyuşturucu veya uyarıcı madde satışına ilişkin taraflar arasında gerçekleşen sözleşmeler konusu suç teşkil ettiğinden hukuken bir geçerliliğe sahip değildir ${ }^{37}$.

Uyuşturucu veya uyarıcı maddenin başkasına verilmesi TCK m. 188/ 3'te düzenlenen bir diğer seçimlik harekettir. Başkasına verme, bir kişiye herhangi bir bedel karşılığı olmaksızın uyuşturucu veya uyarıcı maddenin devredilmesidir. Başka bir söyleyişle satma hareketinin bedelsiz halini ifade etmektedir ${ }^{38}$.

Uyuşturucu maddenin nakledilmesi, uyuşturucu veya uyarıcı maddenin bir yerden başka bir yere taşınmasıdır. Sevk etmek ise bir kimsenin maliki veya zilyedi olduğu uyuşturucu veya uyarıcı maddeyi kullanma amacı d1şında bir amaçla bir yerden başka bir yere, bir başkası aracılığıyla göndermesidir. Sevk etmede madde bizzat fail tarafından götürülmemekte, nakilde ise maddenin götürülmesi bizzat fail tarafindan gerçekleştirilmektedir ${ }^{39}$.

Depolama, uyuşturucu veya uyarıcı maddenin herhangi bir yerde tutulmasıdır. Kişinin doğrudan hâkimiyet alanında bulunduramayacağı veya kontrol edemeyeceği miktarda maddeyi belli bir yerde saklaması veya depolamasıdır. Bunun yanında depolamanın kullanım amaciyla yapılmaması gerekir. Aksi halde, TCK m. 191'de düzenlenen bulundurma söz konusu olur ${ }^{40}$.

TCK m. 188/3'te düzenlenen diğer seçimlik hareketler ise satın alma, kabul etme ve bulundurmadır. Satın alma, uyuşturucu veya uyarıcı maddenin

35 Weber, Klaus: Betäubungsmittelgesetz, 5. Bask1, München 2017, § 29, Rn. 357; Yaşar, s. 225.

36 Körner/Patzak/Volkmer, $\S \S 29$, Rn. 71.

37 Weber, BtMG $\S 29$, Rn. 353.

38 Yokuş Sevük, s. 362.

39 Yurtcan, s. 62.

40 Özbek/Doğan/Bacaksız, s. 785. 
bir bedel karşılığında devralınmasını ifade eder. Kabul etme ise uyuşturucu veya uyarı madde üzerinde tasarrufta bulunma olanağının elde edilmesidir. Son olarak bulundurma, uyuşturucu veya uyarıcı madde üzerinde fiili egemenlik ilişkisinin devam ettirilmesidir. Bu anlamda bulundurma kesintisiz suç niteliğindedir ${ }^{41}$.

TCK m. 191'de düzenlenen seçimlik hareketlerden satın alma, kabul etme ve bulundurma TCK m. 188/3'te bahsedilen hareketler ile aynidır. Farklı olarak kanun koyucu kullanmayı da bir diğer seçimlik hareket olarak düzenlemiştir. $\mathrm{Bu}$ durum aynı zamanda suçun bağlı hareketli olduğunu ortaya koymaktadir ${ }^{42}$.

Kullanma hareketi, 18.06.2014 tarihinde 6545 sayılı Kanun'la TCK m. 191'e eklenmiştir. Bu kapsamda kullanmanın şekli önemli değildir. Önemli olan uyuşturucu veya uyarıcı maddenin vücudun herhangi bir organına veya sistemine etki etmesidir. Bu anlamda uyuşturucu madde herhangi bir etki yapmayacak derecede az miktarda olmamalıdır. Uyuşturucu veya uyarıcı maddenin nasıl ve hangi araç veya teknikle kullanıldığının, niteliğinin ise bir önemi yoktur ${ }^{43}$.

TCK m. 1881/1, 3'de düzenlenen suçlar kasten işlenebilir. Suçun olası kast ile işlenmesi de mümkündür ${ }^{44}$. Failin uyuşturucu veya uyarıcı maddeyi kullanma amacı ile bulundurmaması gerekir. Aksi halde fiil, TCK m. 191'de düzenlenen suçu oluşturacaktır. Failin kullanmak için veya ticari maksatla bu maddeleri bulundurduğunun tespiti somut olayın özelliklerine göre belirlenecektir ${ }^{45}$. Ancak, şu hususu belirtmek gerekir ki uyuşturucu veya uyarıcı maddelerin parasız devredilmesi dahi TCK m. 188/3 uyarınca suç sayılmış$\operatorname{tir}^{46}$.

Üretilen, ithal veya ihraç edilen malın uyuşturucu veya uyarıcı madde olduğu da bilinmelidir. Bunun yanında hukuka aykırılık tipte özel olarak vurgulandığı için fail suça konu maddenin ruhsatsız veya ruhsata aykırı

\footnotetext{
$41 \quad$ Yurtcan, s. 63.

42 Tezcan/Erdem/Önok, s. 1017.

43 Özbek/Doğan/Bacaksız, 811.

44 Aksüt, s. 172; Öner, s. 123.

45 Örneğin, öğretmenin öğrencisinden ele geçirdiği uyuşturucu maddeyi kolluk görevlilerine teslim etmek amaciyla alıkoyması halinde teslim edilene kadar bu maddeye fiilen hâkim olunması suç teşkil etmez. Exner, Thomas: Einführung in das Betäubungsmittelstrafrecht, JuS 2019, s. 214, www.beck-beck.online.de erişim tarihi 15.05.2021.

46 Yurtcan, s. 62.
} 
olarak ürettiğini, ithal ve ihraç ettiğini bilmelidir ${ }^{47}$. Şayet uyuşturucu veya uyarıcı maddenin satın alınması, kabul edilmesi veya bulundurulması kullanmak amacıyla gerçekleştirilmişse TCK m. 191 uyarınca uygulama yapılması gerekir. Failin suça konu şeyin uyuşturucu veya uyarıcı madde olduğunu bilmemesi halinde tipiklikte yanılma söz konusu olur. Bu durumda TCK m. 30/1 uyarınca kastı ortadan kaldıran bir hata hali vardır.

TCK m. 188/1 ve 3'te uyuşturucu veya uyarıcı maddelerle ilgili öngörülen seçimlik hareketlerin "ruhsatsız veya ruhsata aykırı" nitelikte olması aranmıştır. Tıbbi amaçlarla da bu maddelerin kullanılması mümkün olduğundan izne dayalı olarak seçimlik hareketlerin gerçekleştirilmesi halinde bir hukuka uygunluk sebebinden söz edilmelidir. TCK m. 191'de ise fiilin hukuka aykırılığı özel olarak vurgulanmamıştır. Dolayısıyla bu suçun gerçekleşmesinde ayrıca hukuka aykırılık bilinci aranmamaktadır ${ }^{48}$.

\section{BAZI ÜLKE HUKUKLARINDA DURUM}

\section{A. Genel Açılamalar}

$\mathrm{Bu}$ bölüm altında, çeşitli ülke hukuklarında meselenin ne şekilde ele alındığ 1 incelenecektir. Öncelikle, karşılaştırmalı hukukta kişisel kullanım amacının belirlenmesi ve hangi hallerde uyuşturucu madde ticaretinin gerçekleştiğine ilişkin izlenilen yöntemlere yer verilecektir. Genel bir değerlendirmeden sonra kimi ülkeler bakımından mevzuat ve yargı kararları ışığında bir değerlendirme yapılacaktır.

\section{B. Uyuşturucu veya Uyarıcı Maddelerin Hangi Amaçla Fiili Hâkimiyet Altında Bulundurulduğunun Belirlenmesine Yönelik Yöntemler}

Uyuşturucu veya uyarıcı maddelerin hangi maksatla fiili hâkimiyet altında bulundurulduğunun tespitine yönelik karşılaştırmalı hukukta iki farklı yöntem kullanılmaktadır. Bu yöntemlerden ilki eşik miktarlar yöntemi (the threshold quantities), diğeri ise esnek yöntem (flexible model) veya başka bir deyişle ihtiyari sistemdir (discretionary system). Eşik miktarlar yönteminde bir miktar belirlenmekte, belirlenen bu miktara göre uyuşturucu maddeye hangi amaçla sahip olunduğu tespit edilmektedir. Günümüzde en çok tart1şlan yöntem eşik miktarlar yöntemidir. Esnek sistemde ise eşik miktardan farklı olarak uyuşturucu maddenin miktarı hâkimin kanaatini oluşturması

$47 \quad$ Soyaslan, s. 491; Kıdıl, s. 239; Sevdim, s. 157.

48 Özbek/Doğan/Bacaksız, s. 813. 
bakımından bir ölçüt olarak ele alınmakta, somut olayın tüm koşulları çerçevesinde bir değerlendirme yapılmaktadır ${ }^{49}$.

Eşik miktarların kabulünün faydalarının yanında bazı sakıncaları da vardır. Öncelikle, pratik bir çözüm sunması sebebiyle bu miktarların kabulü kanun koyucuların ilgisini çekmektedir. Bu sayede kullanma ve ticaret gibi çetrefilli bir meselenin tespitinde kolaylık sağlanmış olur. Kolluk görevlileri, soruşturma makamları ve mahkemeler hızlı bir biçimde ve daha az kaynak sarfiyatıyla meseleyi çözebilirler ${ }^{50}$. Ancak, usul ekonomisi açısından elde edilen bu menfaatler başka yönlerden ortaya çıkabilecek olumsuz sonuçların gölgesinde kalabilir. Gerçekte kullanıcı olan şahısların uyuşturucu veya uyarıcı madde ticareti yapmaktan veya temin etmekten ceza almaları mümkündür. Kamuoyunda masum kişilerin cezalandırıldığına dair olumsuz kanaatin oluşması ceza adaleti sistemi bakımından arzu edilen bir sonuç değildir ${ }^{51}$.

Karşılaştırmalı hukukta bazı uygulamalardan anlaşılacağı üzere eşik miktarlar cezaevinde bulunan hükümlü ve tutuklu sayısını artırabilir. Söz gelimi, Peru'da kişisel kullanım bakımından sınır miktarlar öngörülmüştür. 2000 yılında kanun yürürlüğe girdikten sonra tutuklama sayılarında ciddi bir artış yaşanmıştır. Uyuşturucu satıcılarının bu durumdan istifade ettikleri, eşik miktarların altında madde bulundurmak suretiyle ticaret veya temin etme suçlarından takibata uğramaktan kurtuldukları gözlenmiştir. Keza, Meksika'da 2008 yılında eşik miktarlar kabul edilmiş, bu sayede uyuşturucu madde kullanıcıları ile satıcılarının ayırt edilmesi amaçlanmıştır. Söz gelimi, kokain için 0.5 gram olarak eşik miktar belirlenmiş, bu miktarla yakalanan bir kişinin kullanma amacı ile hareket ettiği kabul edilmiştir. Ancak, sokak satıcılarının yine 1 gram şeklinde üretime devam ettikleri görülmüştür. $\mathrm{Bu}$ durum cezaevlerinin uyuşturucu kullanıcıları ile dolmasına sebep olmuştur ${ }^{52}$.

Eşik miktarlar ile ilgili ülke mevzuatlarında tayin usulü bakımından farklılıklar vardır. Kimi ülkelerde eşik miktarlar doğrudan kanun koyucu tarafından belirlenmiştir (örneğin Kıbrıs). Bazı ülkelerde bu tespit hükümet veya bakanlıklara bırakılmıştır (örneğin Belçika). Kimi ülkelerde ise kul-

49 Zuffa, Grazia: How To Determine Personal Use In Drug Legislation, The "Threshold Controversy" In The Light Of The Italian Experience, Series on Legislative Reform of Drug Policies Nr. 15, s. 1, https://www.tni.org/files/download/dlr15.pdf, erişim tarihi 15. 05.2021.

50 Zuffa, s. 1.

51 Harris, Genevieve: Conviction by Numbers, Threshold Quantities for Drug Policy, Series on Legislative Reform of Drug Policies Nr. 14, s. 1, http://fileserver.idpc.net/ library/Threshold-quantities-for-drug-policy.pdf, erişim tarihi 15.05.2021.

52 Harris, s. 7. 
lanma amacının olup olmadığının takdiri içtihat hukukuna ait bir meseledir (örneğin Almanya). Keza, kolluk görevlilerine ve soruşturma makamlarına yönelik yönergelerle de meselenin tayin edildiği görülmektedir (örneğin Norveç). Ancak, bu durum eleştirileri de beraberinde getirmiştir. Kolluk veya soruşturma makamlarına işin bırakılmasının hukuki güvenlik açısından sorun teşkil ettiği ifade edilmiştir. Bu makamların hangi olaylara öncelik verileceği hususunda takdir yetkilerinin bulunmasının, demokratik bir toplumda, vatandaşların güvenliği açısından kaygılar taşıdığı belirtilmiştir ${ }^{53}$.

Bazı ülkelerde ele geçirilen uyuşturucu maddenin toplam ağırlığına (örneğin İngiltere); bazı ülkelerde içeriğindeki aktif maddeye (örneğin Hollanda); bazı ülkelerde uyuşturucu maddenin sokak değerine (örneğin İrlanda) önem verildiği görülmektedir. İlk bakışta uyuşturucu maddenin saflık derecesinin adil bir kriter olduğu düşünülebilir. Saflık derecesi aynı zamanda ceza miktarının belirlenmesinde faydalı olabilir. Öte yandan saflık miktarının tespiti toplam miktarı esas alan bir yönteme göre göre daha masraflı olabilir. Tespiti için belli bir zaman, emek, kaynak ve uzmanlık bilgisi gereklidir. Bu ise ancak kriminal laboratuvarlarda mümkündür. Böylesi imkânların olmadığı durumlarda bunun kolluk görevlileri marifetiyle veya ilkel yöntemlerle tespit edilmesi sağlıklı sonuçlar vermeyecektir. Söz gelimi, Pakistan'da kolluk görevlileri yeterli teçhizatları olmadı̆̆ından bahisle yakınmaktadır. Keza, kusur durumu itibarıyla böylesi imkânlara sahip olmayan ve denetleme olanağı bulunmayan kullanıcılar açısından haksız sonuçların doğması kaçınılmazdır ${ }^{54}$.

Bazı ülkeler uyuşturucu maddeyi az veya çok olmak üzere (örneğin Estonya ve Almanya) ayırmakta ve buna göre nitelikli halleri tespit etmektedir. Bazı ülkelerde ise günlük kullanılabilecek uyuşturucu miktarı (örneğin Norveç) veya günlük uyuşturucu kullanım sayısı (örneğin Portekiz'de on günlük kullanım miktarı belirlenmiştir) esas alınmaktadır. Bu hesaplamalar diğer uyuşturucu maddeler bakımından ve onların zararlı etkileri dikkate alınarak yapılmaktadır. Ancak, miktarlar ülkeden ülkeye değişmektedir. Bazen aynı ülke içinde (örneğin Avusturya) eyaletler arasında farklılıklar görülmektedir. $\mathrm{Bu}$ ise karışıklığa yol açmakta ve nihayetinde matematiksel hesaplamanın böylesine farkl1lık arz etmesi eleştirilmektedir ${ }^{55}$.

Eşik miktarlar failin kastının belirlenmesinde faydalıdır. Ancak, bu her zaman sağlıklı sonuçlar vermeyebilir. Mesela, kişi limit değerin üzerinde bir

\footnotetext{
53 Harris, s. 4.

54 Harris, s. 3.

55 Harris, s. 4
} 
miktarla yakalanmış olabilir. Bu durumda failin kastının tartışma götürmez bir biçimde kişisel kullanım dışında bir amaca yönelik olduğu iddia edilemez. Fail uyuşturucu bağımlısı olup ilk kez veya ara sıra uyuşturucu kullanan kişilere göre daha yüksek miktarlarda madde tüketebilir. Keza, fail yakalanma riski sebebiyle tek seferde amaca ulaşmak veya daha ucuz bulduğu için fazlaca miktar almak isteyebilir. Sayılan ihtimaller bakımından madde miktarının kusurluluğu veya toplumsal zararı artırdığı söylenemez. Aksi yönde, eşik değerin altında bir miktarla yakalanan kişinin kullanım amacı dışında hareket ettiğine dair deliller bulunabilir: söz gelimi, dijital tartı aleti, müşteri listesi, telefon kayıtları, nakit para veya benzer suçlardan sabıka kaydı gibi. Bu sebeplerle uyuşturucu maddenin miktarına bakılarak tek başına kastın veya ceza miktarının belirlenmesi sağlıklı sonuçlar vermez ${ }^{56}$.

Doktrinde eşik miktarların faydaları kadar zararlarının da olduğu, bu sebeple esnek yöntemin belirlenmesinin yerinde olduğu ifade edilmiştir ${ }^{57}$. Nitekim Uluslararası Narkotik Kontrol Birimi (INCB) tarafından hazırlanan raporda, eşik miktarlarla ilgili olarak orantılılık ilkesi bakımından ihtiyatlı davranılması gerektiği ifade edilmiştir. Buna göre, güvenilir ve adil sonuçlara ulaşılması için miktara dayalı ceza vermeyi öngören sistemlerin teknik imkânlar, yeterli mali kaynaklar ve insan kaynakları ile desteklenmesi gerektiği belirtilmiştir ${ }^{58}$.

\section{Almanya}

Almanya'da 1960'lı yılların sonunda uyuşturucu madde suçları artış göstermiştir. Bu dönemde 1929 tarihli Opiumgesetz yürürlükteydi. 1971 yılında "Betäubungsmittelgesetz veya BtMG" kabul edilmiş ve uyuşturucu madde suçları yaptırıma bağlanmıştır. Kanun, 1961 tarihli Uyuşturucu Maddeler Tek Sözleşmesine ve 1971 tarihli Psikotrop Maddeler Sözleşmesi'ne dayanmaktadır. Yürürlük tarihinden sonra birkaç kez değişikliğe uğramıştır. "Betäubungsmittel" kavramı uluslararası sözleşmeler kapsamında tüm uyuşturucu ve psikotrop maddeleri ifade etmektedir ${ }^{59}$.

\footnotetext{
56 Harris, s. 4.

57 Harris, s. 4.

58 Report of the International Narcotics Control Board for 2007, s. 9, https://www.incb.org/ documents/Publications/AnnualReports/AR2007/AR_07_English.pdf erişim tarihi 15.05.2021.

59 Tarihi gelişim için Country Legal Profile: Germany, https://www.emcdda.europa.eu/ html.cfm/index5174EN.html\# erişim tarihi 30.01.2021. Alman hukukunda BtMG'de uyuşturucu maddenin tanımı yapılmamıştır. Kanun'un 1. maddesinde yapılan açıklama soyut özelliklere dayanmamakta, daha çok Kanun'un ekinde yer alan listeye atıfta
} 
BtMG'nin $§ \S 29$ ile 34. maddeleri arasında farklı suç tiplerine, idari yaptırımlara ve ek hükümlere yer verilmiştir ${ }^{60}$. Kanun'da ceza miktarları bakımından uyuşturucu maddelerin türlerine göre bir ayrım yapılmamıştır. Hâkim, somut olayın özelliklerine göre suçun konusu olan uyuşturucu maddenin insan sağllğı için tehlikeliliğini göz önünde bulundurur. Uygulamada suçun konusunun esrar olması, özellikle az miktarlarda bulunması halinde genellikle daha az ceza öngörülmektedir ${ }^{61}$.

Alman hukukunda uyuşturucu madde kullanımı suç olarak kabul edilmemektedir ${ }^{62}$. Ancak, uyuşturucu maddenin herhangi bir yazılı izin olmadan bulundurulması veya edinilmesi BtMG $\S \S 29 / 1$ uyarınca cezalandırılmaktadır. Alman hukukunda kullanımın cezasız olduğu hallere, bir arkadaş grubu içerisinde uyuşturucu maddenin birlikte içilmesi veya bir arkadaş ziyareti sırasında düşük miktarda bir kokain maddesinin alınıp hemen buruna çekilmesi örnek gösterilebilir. Çünkü bu durumda kişi hemen uyuşturucu maddeyi kullanmakta ve fiili hâkimiyeti altında bulundurmamaktadır. Buna hoşsohbet ortamı denilmektedir ${ }^{63}$.

bulunmaktır. BtMG anlamında bu maddeler, yalnızca Kanun'un Ek I ila III'te listelenen maddelerdir. Bu listede yer alan maddeler yönetmelikle genişletilebilir, değiştirilebilir. $\mathrm{Bu}$ yetki idareye verilmiştir. Heinrich/Van Bergen, s. 322.

60 Alman hukukunda uyuşturucu maddelerle ilgili düzenlemeler özünde idare hukuku ile ilgili meselelerdir. Esasen narkotik maddelerin kamu hukuku tarafindan izin verilen kullanımı düzenlenmektedir. Örneğin, tıp alanında uyuşturucu maddelerin kullanılması zorunludur. Heinrich/Van Bergen, s. 322.

61 Country Legal Profile: Germany.

62 Kanun koyucu BtMG $\S \S 29 /$ I'de kullanımı cezalandırmamaktadır. Ancak, hukuka aykırı bir biçimde uyuşturucu maddelerin satın alınması veya bulundurulması cezai sorumluluk gerektirdiğinden, kullanımın cezasız kalması neredeyse imkânsızdır. Suç teşkil etmeyen bir tüketim ancak kullanıcının uyuşturucu maddeyi başka birinden aldıktan sonra hemen tüketmesi ve maddenin fiziki varlığı üzerinde herhangi bir imha-kontrol yetkisinin olmaması halinde düşünülebilir. Bu durumlarda dahi, tüketicinin narkotik maddeleri başkasına vermesine veya geri vermesine izin verilmez. Aksi halde uyuşturucu madde temini nedeniyle cezalandırma yapılabilir. Suç oluşturmayan tüketim teorik olarak mümkündür. Ancak, uygulamada BtMG $\S \S 29 /$ I uyarınca hareketlerin birbiriyle sıkı bağlantısı sebebiyle bu durum çok nadir görülebilir veya neredeyse imkânsızdır. Heinrich/Van Bergen, s. 323 vd; benzer yönde Exner, s. 214.

63 Heinrich/Van Bergen, s. 323. Uyuşturucu maddeye sahip olma hareketi (zilyetlik) içtihat hukukunda ve doktrinde açıklanmamıştır. Her hâlükârda, gerçek bir egemenlikhâkimiyet ilişkisi, belirli bir süre için şey üzerinde engelleme olmaksızın kullanabilme olasılı̆̆ ile uyuşturucu maddeye ilişkin bilinçli bir fiili hâkimiyetin bulunması gerekir. Fiili hâkimiyet amacı olmadan kısa süreliğine- bir anlığına almalar buna dâhil değildir. Bir sosyal turda sigarayı bir anlık elinde tutan kişi sosyal tura katılmakta, çektikten sonra diğerine vermektedir. Keza, kocasının esrar ihtiva eden sigaralarını arada sırada içen eş yönünden "bulundurma" olgusu gerçekleşmez. Bu durumda eşin uyuşturucu 
Kanun'un $\S \S 31$ a paragrafı uyarınca uyuşturucu maddenin az miktarda olması, suçun takibinde kamu yararının bulunmaması halinde kamu davasının açılmasından vazgeçilebilir. Keza BtMG $\S \S 29 / 5$ uyarınca mahkeme, failin kişisel kullanımı için önemsiz sayılabilecek miktarda uyuşturucu madde bulundurması halinde ceza vermekten vazgeçebilir ${ }^{64}$.

BtMG'nin müzakereleri sırasında miktar bakımından bir belirlemeden kaçınılmıştır. Bunun yerine "önemsiz miktar (geringe menge)" (§§ 29/5; §§ 31/1) terimi tercih edilmiştir ${ }^{65}$. Bu terim suçun normatif bir unsurunu teşkil etmektedir $^{66}$. Aynı zamanda kastın belirlenmesinde dikkate alınmaktadır ${ }^{67}$. Madde miktarının önemsiz sayılamayacak miktarda olması hali ise "nicht geringe menge" ( $\S 29 / 1-\mathrm{nr} 2 ; \S \S 30 / 1-\mathrm{nr} 4 ; \S \S 30 \mathrm{a} / 1$ ve 2-nr 2) ile ifade edilmiştir. Bir maddenin önemsiz sayılacak veya önemsiz sayılamayacak miktarda olduğunu tespit etme görevi içtihat hukukuna bırakılmıştı́ ${ }^{68}$.

Alman Anayasa Mahkemesi, 9 Mart 1994 tarihinde verdiği bir kararında uyuşturucu maddenin kişisel tüketim amaciyla kullanılması halinde yeni standartların getirilmesini öngörmüştür. Mahkeme, esrar kullanımının ceza yaptırımı suretiyle önlenmesinin Anayasaya uygun olduğunu kabul etmiştir. BtMG'nin orantılılık, eşitlik ve kişi özgürlüğünü ihlal etmediğini kararında vurgulamıştır. Ancak, Mahkeme esrarın kişisel kullanımı halinde uygulama birliğinin sağlanması amacıyla bazı kıstasların kabul edilmesini öngörmüştür. Keza, §§ 31a uyarınca kişisel kullanım sebebiyle kamu davasının açılmaması gerektiği hallerde benzer kıstasların kabul edilmesi kararda belirtilmiştir. Anayasa Mahkemesi, 29 Haziran 2004 (BVerfG, 2 BvL 8/02) ve 30 Haziran 2005 (BVerfG, 2 BvR 1772/02) tarihli kararlarında da bu duruma atıf yapmıştır ${ }^{69}$.

veya uyarıcı maddeyi serbest bir biçimde elden çıkarma gücü olmadığından, mahkeme bunu fiili hâkimiyet olarak kabul etmemiştir. Ancak, sosyal turda bir sonraki kişiye maddenin tadını çıkarması için bırakılması durumunda fiili hâkimiyetin kurulmuş olduğu kabul edilmiştir. OLG Köln, Beschluß vom 07.10.1980 - 1 Ss 692/80. Karar için bkz. www.beck-beckonline.de erişim tarihi 15.05.2021.

64 The role of the quantity in the prosecution of drug offences, European Legal Database on Drugs, https://www.emcdda.europa.eu/system/files/publications/10503/Quantities. pdf erişim tarihi 30.01.2021.

65 Weber, $\S 29$, Rn. 54.

66 Uyuşturucu maddeler sürekli değiştiğinden ve geliştiğinden kanun koyucunun bir miktar belirlemesi uygun değildir. Görüşler için bkz. Schäfer/Sander/Von Gemmeren, BtMG, Rn. 1753.

67 Oğlakçıŏ̆lu, $\S 29$, Rn. 74.

68 Oğlakçıoğlu, § 29, Rn. 196.

69 The role of the quantity in the prosecution of drug offences. 
Anayasa Mahkemesi'nin 1994 tarihli kararı üzerine Federal hükümet, önemsiz miktarda esrarın neyi ifade ettiği hususunda eyalet Adalet Bakanlıklarına çağrıda bulunmuştur. Ancak, eyalet bakanlıkları tek tip bir ilkede anlaşamamışlardır. Mahkemeler ise uyuşturucu maddenin türü ile ilgili olarak bazı ilkeler ve miktarlar kabul etmişlerdir ${ }^{70}$.

İçtihat hukukuna bakıldığında aşağıdaki miktarlarda uyuşturucu veya uyarıcı maddenin fiilî hâkimiyet altında bulundurulması halinde önemsiz sayılamayacak bir miktar söz konusudur. Örneğin, 10 gram amfetamin, 7.5 gram esrar, 1.5 gram eroin, 5 gram kokain ve metamfetamin ile 4.5 gram baz morfin az sayılmayacak miktar kabul edilmektedir. Bunların altındaki miktarlar ise az miktar sayılmaktadır ${ }^{71}$. İçtihat hukukunda, bu maddelere ilişkin her dozda kullanılabilecek uyuşturucu veya uyarıcı madde miktarı ve bu miktarın kaç doz kullanıma karşılık geldiği tespit edilmiştir. Buna göre, amfetamin için kişisel doz miktarı 50 mg olup, 200 doza kadar kullanım; esrar için kişisel doz miktarı15 mg olup, 500 doza kadar kullanım; eroin için kişisel doz miktarı $50 \mathrm{mg}$ olup, 30 doza kadar kullanım; kokain için kişisel doz miktarı $33 \mathrm{mg}$ olup, 150 doza kadar kullanım; metamfetamin ve baz morfin için kişisel doz miktarı 100mg olup, 45 doza kadar kullanım ${ }^{72}$.

Sınır değerler belirlenirken maddenin içeriğindeki etken maddeye (saflık miktarına) ve insan sağlığ için arz ettiği tehlikeye bakılmaktadır ${ }^{73}$. Tespit yapılırken yeni kullanıcılar ile ara sıra uyuşturucu madde kullanan kişiler esas alınmaktadır ${ }^{74}$. Temel amaç ilk kez kullanan kişilere maddenin ulaşmasin1 engellemektir ${ }^{75}$.

70 Country Legal Profile: Germany.

71 Doktrinde, BtMG $\S \S 29 /$ I'de açıkça ifade edilmemesine karşın, bir üçüncü miktarın yani normal miktarın da olduğu ifade edilmiştir. Normal miktar, az miktar ile az sayılmayacak miktar arasındadır. Normal miktara yönelik cezalar adli para cezası veya beş yıla kadar hapis cezasıdır. Kirmse, Claudia: Betäubungsmittelstrafrecht - Ein Überblick für Referendare, Juristische Arbeitsblätter, 2011, s. 613, www.beck-beck.online.de erişim tarihi 15.05.2021.

72 Önemsiz miktarlar için bkz. Körner/Patzak/Volkmer, § 29, Rn. 48-106. Liste için ayrica bkz. Exner, s. 212.

73 Oğlakçıŏlu, § 29, Rn. 217; Krumm, Carsten: "Die "nicht geringe menge" im Betäubungsmittelstrafrecht", NJW 2020, 2165, www.beck-online.de erişim tarihi 30.01.2021; Leipold, Klaus: Das Betäubungsmittelstrafrecht, NJW Spezial, 2004, s. 375, www.beck-beck.online.de erişim tarihi 15.05.2021.

74 Schäfer/Sander/Von Gemmeren, BtMG, Rn. 1751; Gunnar, Cassardt: Zur Feststellung der nicht geringen Menge im Betäubungsmittelstrafrecht, NStZ 1995, s. 257, www.beck-beck.online.de erişim tarihi 15.05.2021.

75 Körner/Patzak/Volkmer, $\S \S 29$, Rn. 130; Weber, $\S \S 29$, Rn. 70. 
Narkotik maddelerin tümü için esasen tek bir miktarın belirlenmesi mümkün değildir. Bu sebeple maddenin etki ve tehlikelilik derecesi (ölüm ihtimali), niteliği, yoğunluğu, ortalama tüketici davranışları gibi sebepler dikkate alınarak bir dozun ne kadar olduğu ve en fazla kaç doz madde kullanılabileceği hesaba katılarak sınır miktarlar belirlenmiştir ${ }^{76}$. Önemsiz sayılmayacak miktardaki basit aşmalar başka delillerin bulunmaması halinde sanığın lehinde değerlendirilmektedir ${ }^{77}$. Madde miktarı ile ilgili böyle bir hata Alman hukukunda suçun maddi unsurlarında hata olarak kabul edilmektedir ${ }^{78}$.

Failin ticaret kastı ile hareket etmesi halinde önemsiz sayılacak bir miktar yönünden de ceza verilebilir. Ancak, failin miktar hususunda yanılgisı lehinde kabul edilmektedir. Failin ticaret kastı ile hareket ettiği iddia edilmekteyse bunun delillerinin ortaya konulması gerekir. Aktif madde içeriğinin sınır değere yaklaştı̆̆ 1 durumlarda failin kastının titizlikle ele alınmas1 gerekir ${ }^{79}$.

\section{Avusturya}

Avusturya hukukunda uyuşturucu suçları ile ilgili ilk temel kanun 1951 yılında yürürlüğe girmiştir. 1951 tarihli Narkotik Maddeler Kanunu'nda 1971, 1974, 1977, 1980, 1985 ve 2017 yıllarında değişiklikler yapılmıştır ${ }^{80}$. 1 Ocak 1998 tarihli "Uyuşturucu Maddeler Kanunu (Suchtmittelgesetz veya SMG) ile bu Kanun yürürlükten kaldırılmıştır ${ }^{81}$. Avusturya hukukunda uyuşturucu ve psikotrop maddeler bu Kanun altında düzenlenmiştir ${ }^{82}$.

Denetim altında uyuşturucu madde kullanılması Avusturya'da suç değildir. Hukuka aykırı bir biçimde uyuşturucu veya psikotrop maddenin fiili hâkimiyet altında bulundurulması suç olarak düzenlenmiştir. Kişisel kullanım amaciyla uyuşturucu maddenin elde edilmesi, bulundurulması, üretilmesi, ihraç veya ithali, taşınması, teslim edilmesi veya temin edilmesi halinde fail altı aya kadar hapis veya 360 gün adli para cezası ile cezalandırılır $(\text { SMG } \S \S 27 / 2)^{83}$.

76 Oğlakçıoğlu, $\S \S 29$, Rn. 208; Weber, $\S \S 29$, Rn. 67; Krumm, "Die "nicht geringe menge" im Betäubungsmittelstrafrecht.

77 Krumm, "Die "nicht geringe menge" im Betäubungsmittelstrafrecht.

78 Oğlakçıŏlu, $§ 29, \mathrm{Rn} .77$.

79 Oğlakçıŏlu, § 29, Rn. 76.

80 Tarihi gelişim için bkz. Country Profile-Austria, https://www.emcdda.europa.eu/ html.cfm/index5174EN.html erişim tarihi 30.01.2021.

81 Kanun metni için bkz. https://www.jusline.at/gesetz/smg erişim tarihi 30.01.2021.

82 Körner/Patzak/Volkmer, $\S \S 29$, Rn. 538.

83 Körner/Patzak/Volkmer, §§ 29, Rn. 543,547. 
Avusturya hukukunda uyuşturucu maddenin kişisel kullanım ile ticari maksatla bulundurulması arasında ayrım yapılmıştır. Bu ayrıma göre cezai yaptırımlar belirlenmektedir. Kanun "büyük miktar" kavramına atıf yapmak suretiyle önemli ve daha az önemli suçlar bakımından hükümler öngörmektedir (SMG $\S \S 28)$. Buna göre az miktarda bir uyuşturucu maddenin bulundurulması halinde kovuşturmanın ertelenmesine izin verilmektedir (SMG $\S \S$ 35.1). Bunun yanında kişinin uyuşturucu madde kullanımının sıklığ 1 da dikkate alınmaktadır ${ }^{84}$.

Avusturya'da miktar bakımından bazı limitler öngörülmüştür. 1980 yılında Sağlık Komitesi (Gesundheitsbeirat) küçük ve büyük miktarlarla ilgili tavsiyelerde bulunmuştur. Komite, az miktarı büyük miktarın yüzde onu olarak belirlemiştir. Söz gelimi, eroin için 0.3 gr, kokain için 1,5 gr, amfetamin için $1 \mathrm{gr}$, esrar için ise $2 \mathrm{gr}$ az miktardır ${ }^{85}$. Bu tespitler mahkemeleri bağlayıcı mahiyette olmamakla beraber uygulamada kabul görmektedir. Konu ile ilgili 1985 yılında meclis komitesinde küçük miktarın tanımlanmaması gerektiği yönünde görüş benimsenmiştir. Uyuşturucu maddelerin birbirinden niteliği, içeriğindeki etken maddeler ve bileşimleri itibarıyla farklı olması, kimyasal formülleri ile bir tanım yapılması zarureti söz konusu olduğundan böyle bir tanımlamaya gitmenin mümkün olmadığı ifade edilmiştir $^{86}$.

Federal Çalışma, Sağlık ve Refah Bakanlığı ile Adalet Bakanlığının işbirliği ile çıkarılan kararname uyarınca uyuşturucu veya uyarıcı madde miktarına ilişkin miktarlar belirlenmiştir. Buna göre suçun konusunun $30 \mathrm{mg}$ MDMA, 15 gr kokain, 10 gr amfetamin, 3 gr eroin, 20 gr esrar olduğu hallerde SMG $\S$ 28B uyarınca ceza artırılmaktadır. Bu miktarlar Kanun'da tarif edilen büyük miktarlardır. Miktarın tespitinde elde edilen maddenin ihtiva ettiği etken madde, içeriğinde ne kadar saf madde veya tuzlarını bulundurduğu dikkate alınmaktadır ${ }^{87}$.

84 Country Profile-Austria.

85 Verordnung der Bundesministerin für Arbeit, Gesundheit und Soziales über die Untergrenzen einer großen Menge (Grenzmengen) bezüglich der Suchtgifte (SuchtgiftGrenzmengenverordnung-SGV), https://www.ris.bka.gv.at/GeltendeFassung.wxe? Abfrage $=$ Bundesnormen \&Gesetzesnummer $=10011056 \&$ FassungVom=2009-06-15 erişim tarihi 30.01.2021.

86 The role of the quantity in the prosecution of drug offences.

87 Körner/Patzak/Volkmer, §§ 29, Rn. 545; Alexender, Lichtenegger, Die Bedeutung von Mengen für die Strafbarkeit von Verstößen nach dem Suchtmittelgesetz, s. 8, https://epub.jku.at/obvulihs/download/pdf/2934194? originalFilename=true erişim tarihi 11.03.2021. 
Avusturya hukukunda kişisel kullanım amacının belirlenmesi soruşturma ve kovuşturma makamlarına bırakılmıştır. Sanığın maddeyi bulundurma amacı, suçun konusunun yarattığı tehlikelilik ve somut olayın koşullarına göre belirlenir ${ }^{88}$.

\section{E. Belçika}

Belçika hukukunda uyuşturucu ve uyarıcı madde suçlarını düzenleyen kanun 24 Şubat 1921 tarihinde kabul edilmiştir ${ }^{89}$. Kanun ile uyuşturucu maddelerin ticareti kurallara bağlanmıştır. Kanun'da uyuşturucu madde kullanımı ile ticareti arasındaki ayrımın belirlenmesinde miktara dayalı sınırlar öngörülmemiştir. Keza, uyuşturucu maddenin türü, niteliğine dayalı bir ayrım da yapılmamıştır ${ }^{90}$. 06.09.2017 tarihli Kraliyet Kararnamesi ile hangi maddelerin bu kapsamda sayılacağ 1 gruplara ayırmak suretiyle belirlenmiştir. Ayrıca, sentetik maddelerde yaşanan gelişmelere ayak uydurulması amaçlanmıştır $^{91}$.

Belçika hukukunda 2 Haziran 2003'ten beri 3 gram veya daha fazla miktarda esrar veya esrar reçinesinin bulundurulması suç kabul edilmiştir. Ancak, daha fazla miktarda esrarın bulundurulması da kullanma sınırında kabul edilebilir. Failin daha uzun süre için kullanmak amacıyla uyuşturucu maddeyi bulundurduğuna dair diğer delillerin bulunması halinde benzer şekilde uygulama yapılabilmektedir ${ }^{92}$.

Cezalandırma için suçun konusu olan esrar maddesinin içeriğindeki THC'nin aktif bileşen miktarının yüzde $0,2^{\prime}$ 'nin üzerinde olması gerekir ${ }^{93} . \mathrm{Bu}$ durumda fail, ilk fiilinden dolay1 75 ila 125 Euro arasında bir adli para cezas1 ile cezalandırılır. Bir yıllık süre zarfında sonraki kullanımlarda para cezası artmaktadır. Benzer yaptırım kişisel kullanım amacıyla Hint keneviri yetiştirilmesinde de uygulanmaktadır. Esrar dişındaki uyuşturucu maddelerin bulundurulması halinde ise hapis cezası da öngörülmektedir. Belçika hukukunda esrar dışında uyuşturucu maddelerin bulundurulması, üretilmesi, satın alınması, nakli üç aydan beş yıla kadar hapis ve 1.000 Euro'dan 100.000

88 The role of the quantity in the prosecution of drug offences.

89 Cannabis Regulation in Europe: Country Report Belgium, Şubat 2019, s. 2, https://www.tni.org/files/publication-downloads/cr_belgium_082019.pdf erişim tarihi 30.01.2021.

90 Country Legal Profile: Belgium, https://www.emcdda.europa.eu/html.cfm/index517 4EN.html?pluginMethod=eldd.countryprofiles\&country=BE erişim tarihi 30.01.2021.

91 Körner/Patzak/Volkmer, $\S \S 29$, Rn. 506.

92 Körner/Patzak/Volkmer, $\$ \S 29$, Rn. 513.

93 Körner/Patzak/Volkmer, $\S \S 29$ Rn. 508. 
Euro'ya kadar adli para cezası ile yaptırıma bağlanmaktadır. Nitelikli hallerde ceza miktarı yirmi yıla kadar artırılmaktadır ${ }^{94}$.

\section{F. Danimarka}

Danimarka hukukunda kullanım amacıyla az miktarda uyuşturucu maddenin bulundurulması failin ilk fiili ise uyarılmakla yetinilmektedir ${ }^{95}$. Sonraki kullanımlarda adli para cezası öngörülmektedir. Danimarka Ceza Kanunu'nun (Dan. CK) 191. maddesinin 1. ve 2. fikraları uyarınca nitelikli hallere yer verilmiştir ${ }^{96}$. Buna göre insan sağlığı açısından önemli tehlike arz eden uyuşturucu maddelerin çok sayıda kişiye satılması veya temin edilmesi daha ağır bir biçimde cezalandırılmaktadır. Uyuşturucu maddenin miktarı ile maddenin tehlikelilik derecesi nitelikli halin uygulanmasında dikkate alınmaktadır. Söz gelimi, $10-15 \mathrm{~kg}$ esrar, 25 gram eroin veya kokain, 50 gram amfetamin veya yaklaşık 200 adet ekstazi hap bulundurulması Dan. CK m. 191 uyarınca altı yıla kadar hapis cezası ile cezalandırılmaktadır ${ }^{97}$. Şayet 5 grama kadar eroin, amfetamin veya kokain veya 10 hapa kadar ekstazi bulundurulmuş ise fail adli para cezası ile cezalandırılmaktadır. 0.2 grama kadar eroin veya kokain, 0.5 grama kadar amfetamin veya iki adet ekstazi hap bulundurulması halinde kişi uyarılmakla yetinilmektedir ${ }^{98}$.

94 Country Legal Profile: Belgium.

95 Country Legal Profile: Denmark, https://www.emcdda.europa.eu/html.cfm/ index5174EN.html\# erişim tarihi 02.01.2021; Laursen, Lau/Jepsen, Jorgen: "Danish Drug Policy-An Ambivalent Balance between Repression and Welfare", The Annals of the American Academy of Political and Social Science, Vol. 582, Haziran 2002, s. 20 36.

96 Danimarka Ceza Kanunu için bkz. https://www.legislationline.org/download/id/6372/ file/Denmark_Criminal_Code_am2005_en.pdf erişim tarihi 01.02.2021; 2013 National Report ( 2012 data) to the EMCDDA by the Reitox National Focal Point, DENMARK, New development, Trends, and in-depth information on selected issues, s. 78, https://www.sst.dk/en/health/ /media/35655EAB90EB4B1DB4FC0AFD81E993DB.ash $\mathrm{x}$ erişim tarihi 10.03.2021.

97 Moeller, Kim: "Enforcement Intensity in Danish Drug Control”, 1996-2017, European Journal on Criminal Policy and Research, 2020, s. 4, http://www.diva-portal.org/smash/ get/diva2:1415336/FULLTEXT01.pdf erişim tarihi 02.02.2021; Nygaard-Christensen, Maj/Vibeke Asmussen, Frank: Cannabis Regulation in Europe: Country Report Denmark, Şubat 2019, https://www.tni.org/files/publication-downloads/cr_denmark_ 02052019.pdf erişim tarihi 02.02.2021.

98 Hughes, Caitlin/Stevens, Alex/Hulme, Shann/Cassidy, Rebecca: Review of approaches taken in Ireland and in other jurisdictions to simple possession drug offences, A report for the Irish Department of Justice \& Equality and the Department of Health (and the working group on this issue), Eylül 2018, s. 33, http://fileserver.idpc.net/library/ ANNEXE_I_-_Hughes_Stevens_Hulme_Cassidy_-_2018_- 


\section{G. İtalya}

İtalyan hukukunda uyuşturucu maddelerin hukuka aykırı olarak ticaretine, bulundurulmasına ve örgüt kapsamında suçun işlenmesine yönelik hükümler 309/1990 numaralı Cumhurbaşkanlığı Kararnamesi ile düzenlenmiştir $^{99}$. Kararname'de uyuşturucu maddelere ilişkin bir listeye yer verilmiştir. $\mathrm{Bu}$ liste Adalet Bakanlığı tarafından periyodik olarak güncellenmektedir ${ }^{100}$.

İtalyan hukukunda önceleri eşik miktarlar kabul edilmişti. Esasen eşik miktarlar yöntemi ile esnek yönteme yönelik eleştiriler uyuşturucu madde kullanımının suç olmaktan çıkarılması eğilimi ile bağlantılıdır. İtalyan uygulamasında uyuşturucu suçlarına karşı katı tutum öngören taraflar eşik miktarları; uyuşturucu kullanımının suç olmaktan çıkarılmasını ileri süren görüşler de esnek sistemi savunmuşlardır. Suç olmaktan çıkarma eğilimi uyuşturucu maddeyi fiili hâkimiyet altında bulundurmak yerine temin etmeye odaklanmaktadir ${ }^{101}$.

İtalyan hukukunda uyuşturucu madde kullanma ile ticareti arasındaki ayrımın belirlenmesi açısından "ortalama günlük doz" kavramı kabul edilmişti. Bunun yanında hafif veya daha ağır cezalandırmayı gerektiren haller bakımından belli miktarlar öngörülmüştü. 5 Haziran 1993 tarihinde yapılan referandum sonucunda bu düzenleme iptal edilmiştir ${ }^{102}$. Dolayısıyla fiilin

_Review_of_approaches_taken_in_Ireland_and_in_other_jurisdictions_to_simple_posse ssion_drug_offences.pdf erişim tarihi 02.02.2021.

99 Country Legal Profile: Italy, https://www.emcdda.europa.eu/html.cfm/index5174EN. html\# erişim tarihi 02.02.2021.

100 https://www.hg.org/legal-articles/detention-and-drug-dealing-in-italy-46349) erişim tarihi 30.01.2021.

101 Zuffa, s. 3.

1021988 tarihli Uyuşturucu ve Psikotrop Maddelerin Kaçakçılığına Karşı Birleşmiş Milletler Sözleşmesi imzalandığında Nancy Reagan tarafından ortaya atılan "sadece hayır de! (just say no)" sloganı etkili olmuş ve İtalya'da bu akımın etkisi ile uyuşturucu kullanımına ilişkin daha katı bir yaklaşım benimsenmiştir. 1975 yılında yapılan bir kanuni düzenleme ile kullanma limiti getirilmişti. Bu durum, 1980'li yıllarda yukarıda belirtmiş olduğumuz akımın etkisi ile eleştirilmekteydi. Kullanma limiti belirlenmesinin bir gevşeklik olduğu, uyuşturucu madde kullanımını ve ticaretini artırdığı, takdir yetkisini yargılama makamlarına bıraktığı ve normun bir belirsizlik ortamı yarattığı ileri sürülmüştür. Bu eleştirilere rağmen 1990'lı yıllarda günlük kullanım dozu getirilmiş; bir kişinin ortalama günlük kullanabileceği uyuşturucu miktarı tespit edilmiştir. Bu kabul, esasen kişisel kullanım ile ticaret arasındaki farkın belirlenmesinde faydalı bir kriter değildi; ancak cezanın bireyselleştirilmesi amacına hizmet etmekteydi. Günlük kullanım dozu, Sağlık Bakanlığı tarafından Kanun'un yürürlüğe girmesinden hemen sonra tespit edilmişti: 100 mg eroin, 150 mg kokain, 500 mg esrar günlük kişisel kullanım miktarı olarak belirlenmişti. Bu miktarlar kanun dışı pazarda kullanıcıların aldıkları maddenin ne kadar uyuş- 
hukuki niteliğinin tespitinde uyuşturucu maddelerin miktarına göre düzenleme öngören bir hüküm bulunmamaktadır ${ }^{103}$.

İtalyan hukukunda ticaret veya kullanma amacının belirlenmesi yarg1lama makamlarına bırakılmıştır. Mahkeme kararlarında uyuşturucu veya uyarıcı maddenin miktarı suçun manevi unsurunun belirlenmesinde bir unsur olarak değer görmektedir. Ancak, failin asıl niyetinin madde miktarından daha önemli olduğu kabul edilmektedir. Failin ticari maksatla hareket ettiğinin tespit edilemediği durumlarda yüksek miktarlarda dahi kullanma kapsamında idari yaptırımlara hükmedildiği görülmektedir. Bunun yanında uyuş-

turucu madde içerdiğini tespit etmelerinin güçlüğü sebebiyle eleştirilmiş ve kullanıcı cephesinden meseleye yaklaşıldığında bir belirsizlik yarattığı ifade edilmiştir. Kabul edilen miktarlar bakımından bir esnekliğin bulunmaması da tartışılmaktaydı. Kullanıcıların satıcı gibi cezalandırılmasına sebep olduğu ifade edilmekteydi. İstenmeyen sonuçlardan kaçınmak için, parlamento tartışmaları sırasında hüküm kısmen değiştirilmiş ve önemsiz suçlar bakımından yeni bir hüküm getirilmiştir (lieve entità). Buna göre, eşik miktarlarda öngörülen cezalardan hafif aşmalar halinde temel cezadan üçte birine kadar bir indirime hükmedilmesi kabul edilmişti. Ancak, hüküm aynı zamanda eşiğin üzerinde miktar bulunduran kişiler için zorunlu tutuklama öngörmesi sebebiyle sınırlı bir etkiye sahip olmuştur. Bu durum İtalya'da tutuklu sayısının hızlı bir biçimde artmasına sebep olmuştur. 1991 yılında üç genç kullanıcının eşik miktarın üzerinde uyuşturucu madde ile yakalanması ve tutuklanması üzerine, bu kişilerin cezaevinde intihar etmeleri İtalyan kamuoyunda tepkilere neden olmuştur. Dönemin Adalet Bakanı Claudio Martelli, kanuni düzenlemede bir değişiklik yapılması çağrısında bulunmuş; mevcut düzenlemenin kullanıcılar ile satıcılar arasında bir ayrım yapmaya izin vermediğini ifade etmiştir. Yayınlanan bir kararname ile günlük kullanım dozunda hafif aşmalar sebebiyle zorunlu tutuklama yapılmaması öngörülmüştür. İtalya'da Craxi hükümetinin düşmesinden sonra Amato hükümeti kurulmuş ve günlük kullanım dozunun bireyselleştirilmesi için değişikliğe gidilmiş; kullanıcının şahsi özellikleri, bağımlılık durumu itibarıyla bu miktarın üç kata kadar çıkartılabileceği kabul edilmiştir. Aslında hükümetin bu çalışmasından önce Anayasa Mahkemesi değişikliğin yolunu açmıştır. Mahkeme 10 Temmuz 1991 tarihli ve 333 numaralı kararında, kanun koyucuya düzenlemenin değiştirilmesi çağrısında bulunmuştur. Yargıçlara da günlük doz miktarının uygulamasında katı davranmamaları tavsiyesinde bulunmuştur. Kararda uyuşturucu madde miktarının diğer kriterlerle birlikte ele alınması gerektiği ifade edilmiştir. Nihayetinde, 1993 yılında eşik miktarlar öngören kanuni düzenleme referandum ile iptal edilmiştir. Referandumun sonucunda uyuşturucu madde kullanımı cezai yaptırım olmaktan çıkarılmış, idari bir yaptırıma dönüşmüştür. Söz gelimi, uygulamada pasaporta el konulması, ehliyetin bir süreliğine geri alınması gibi yaptırımlar uygulanmaktadır. Tarihi gelişim için bkz. Zuffa, s. 3 vd.

103 Italy: New drugs law heralds the mass criminalisation of drug users, https://www.statewatch.org/media/documents/news/2004/feb/italy-new-drugs-law.pdf erişim tarihi 30.01.2021; Uygulamada uyuşturucu madde suçları ile ilgili olarak kanunilik modelinin getirildiği görüşü hâkimdir. Bu sebeple ispat yükü savcının üzerindedir. Kullanım amacı dışında bir amaç ile hareket edildiği iddia ediliyorsa delillerinin toplanması, ortaya konulması gerektiği ifade edilmiştir. Görüşler için bkz. Zuffa, s. 5. 
turucu maddenin niteliği ve içeriğindeki etken maddeler, maddenin tartımı ve paketlenmesi için alet kullanılması, farklı türlerde uyuşturucu madde bulundurulması gibi somut olayın özelliklerine göre diğer deliller de göz önünde bulundurulmaktadır ${ }^{104}$.

\section{H. İspanya}

İspanya Ceza Kanunu'nun 368. maddesinde uyuşturucu madde ticareti ile ilgili temel yaptırımlar belirlenmiştir. Maddede insan sağlığı açısından tehlike arz eden nitelikli hallere yer verilmiştir ${ }^{105}$.

Failin kastının belirlenmesinde uyuşturucu maddenin miktarına önem verilmektedir. Ancak, kanun koyucu kişisel kullanım ile ticari amacı birbirinden ayırmak için bir eşik miktar öngörmemiştir. Bunun tespiti, somut olayın tüm koşulları değerlendirilmek suretiyle içtihat hukukuna bırakılmıştır. Uygulamada ticari maksatla uyuşturucu maddenin bulundurulduğuna dair başkaca delil yoksa failin kullanmak için uyuşturucu maddeyi bulundurduğu kabul edilmektedir. Bunun yanında failin daha önce uyuşturucu veya uyarıcı madde kullanıcısı olup olmaması da delillerin takdirinde gözetilmektedir ${ }^{106}$.

\section{I. İsveç}

İsveç hukukunda, uyuşturucu madde suçları ile ilgili temel düzenleme 1968 tarihli Kanun'dur. Kanun'da narkotik maddelere ilişkin ceza hükümlerine yer verilmiştir. Narkotik maddelerin hukuka aykırı bir biçimde üretilmesi, taşınması, temin edilmesi gibi hareketler yaptırıma bağlanmıştır. Uyuşturucu madde kullanımı ise 1988 yılından beri cezalandırılan bir fiildir. İsveç hukukunda uyuşturucu ve uyarıcı maddeler ile ilgili çeşitli kanunlarda hükümler bulunmaktadır.

1968 tarihli Kanun'un 8. maddesinde narkotik maddeler tanımlanmıştır. Buna göre narkotik maddeler bağımlılık yapıcı özelliklere sahip, sağlık için tehlike oluşturan maddelerdir. Kanun'un 2. maddesi uyarınca suçun konusunun miktar bakımından düşük ve niteliği itibarıyla daha az zararlı maddeler olması halinde adli para cezası veya altı aya kadar hapis cezası öngörülmüştür. Uyuşturucu maddenin niteliğine ve miktarına göre fiil önemli

104 Drug offences in Italy: conspirancy, dealing and use, https://canestrinilex.com/en/ readings/drug-offences-in-italy-detention-and-dealing/ erişim tarihi 30.01.2021.

105 İspanya Ceza Kanunu için bkz. https://www.legislationline.org/download/id/6443/ file/Spain_CC_am2013_en.pdf erişim tarihi 15.01.2021.

106 Country Legal Profile: Spain, https://www.emcdda.europa.eu/html.cfm/index5174EN. html\# erişim tarihi 02.02.2021; The role of the quantity in the prosecution of drug offences. 
veya önemsiz kabul edilmektedir. 1993 yılında İsveç hükümeti tarafından önemsiz suçların sadece uyuşturucu maddenin kişisel kullanım amacıyla fiili hâkimiyet altında bulundurulmasını kapsadığ 1 ifade edilmiştir. Ancak, kişisel kullanım amacı ile de olsa uyuşturucu maddenin temini bunun dışındadır. Bunun istisnası faillerin düşük miktarda bir uyuşturucu maddeyi halka halinde birlikte kullanmalarıdır ${ }^{107}$.

İsveç hukukunda uygulamada önemsiz suçlar bakımından bazı eşik miktarlar kabul edilmiştir. Buna göre; 60 gramdan az esrar, 5 gramdan az amfetamin, 0.6 gramdan az kokain veya eroin bu niteliktedir. Önemli suçlar bakımından daha yüksek miktarlar söz konusudur. Buna göre; $2 \mathrm{~kg}$ esrar, 250 gram amfetamin, 50 gram kokain, 25 gram eroin, 160 adet ekstazi hap bulundurulması önemli suçlara örnek gösterilebilir ${ }^{108}$.

\section{KIŞ̧ISEL KULLANIM AMACININ BELİRLENMESINE YÖNELİK KRITTERLER}

\section{A. Genel Açıklamalar}

Uyuşturucu veya uyarıcı maddenin hangi amaçla satın alındığı, kabul edildiği veya bulundurulduğunun tespiti ile ilgili TCK m. 188 veya 191'de bir hüküm bulunmamaktadır. Kanun koyucu suçun manevi unsuru bağlamında hangi suç tipinin gerçekleştiğinin tespitini uygulamaya bırakmıştır. Karşılaştırmalı hukukta görüldüğü üzere kanun koyucu eşik miktarlar belirleme yoluna gitmemiş, esnek sisteme taraf olmuştur. Kanun koyucunun bu kabulü karşılaştırmalı hukukta geçerli olan genel anlayış ile uyumludur.

Avrupa Birliği'ne üye birçok ülke uyuşturucu veya uyarıcı maddenin ticareti ile kullanımı arasında ayrıma gitmekte ve bu doğrultuda düzenlemeler öngörmektedir. $\mathrm{Bu}$ anlamda TCK, benzer şekilde uyuşturucu veya uyarıcı madde imal ve ticareti ile kullanılması ayrımını kabul etmektedir.

Failin uyuşturucu maddeyi hangi maksatla fiilî hâkimiyeti altında bulundurduğu kişinin iç dünyasına ait bir olgudur. $\mathrm{Bu}$ sebeple failin dışa yansıyan davranışlarından yararlanmak suretiyle kastın belirlenmesi mümkündür ${ }^{109}$. Uygulamada kullanma amacının belirlenmesinde Yargıtay'ın bazı kriterleri dikkate aldığı görülmektedir. Bu bölümde, Yargıtay içtihatları 1şığında bir değerlendirme yapılacaktır ${ }^{110}$.

107 Country Legal Profile: Sweden, https://www.emcdda.europa.eu/html.cfm/index5174EN. html\# erişim tarihi 02.02.2021.

108 The role of the quantity in the prosecution of drug offences.

109 Tezcan/Erdem/Önok, s. 995.

110 Yargitay CGK, 19.03.2019, 10-476/218 UYAP. 


\section{B. Failin Hareketleri}

Failin dişa yansıyan davranışları suçun manevi unsurunun tayininde önemlidir. Şayet, suça konu madde, kullanmak için alınmış ise ortada uyuşturucu madde ticareti yoktur. Ancak, düşük miktarda bir uyuşturucu madde söz konusu olsa dahi fail, kazanç sağlamak amacıyla bunu satın almış ise fiil, uyuşturucu madde ticaretini oluşturacaktır. Failin sırf ticari amaçla hareket etmesi; bu doğrultuda uyuşturucu maddeyi satın alması, bulundurmas1, depolaması uyuşturucu madde ticaretinin oluşması için yeterlidir ${ }^{111}$.

Failin kastındaki değişmeler fiilin başka bir suçu oluşturmasına sebep olabilir. Söz gelimi, fail kullanmak amacıyla satın aldığı uyuşturucu maddeyi satmaya karar verebilir. Bu durumda fiil uyuşturucu madde ticaretini oluşturur. Ancak, failin hareketleri ile bunu ortaya koyması, uyuşturucu madde ticareti yönünde bir davranış içerisine girmesi gerekir. Şayet, fail kullanmak için satın aldığı uyuşturucu maddeyi satıp satmama hususunda tereddüt yaşamış, kararsız kalmışsa bu durum failin aleyhinde değerlendirilemez ${ }^{112}$.

Failin, fiili hâkimiyeti altında bulundurduğu uyuşturucu maddeyi satmaya yönelik potansiyel alıcılara ulaşma gayretleri ticarete yönelik hareketlerdir. Bu durumda teşebbüs edilmiş bir fiilden değil, tamamlanmış bir suçtan bahsedilmelidir ${ }^{113}$. Esasen, bu tür davranışlar satışa arz mahiyetindedir. $\mathrm{Bu}$ manada, failin uyuşturucu veya uyarıcı maddeyi satabileceği pazarlar araması, bu amaçla suç mahallerini keşfetmesi, gelir kaynakları ile ilgili araştırmalar yapması, sorular sorması, satışa ilişkin anlaşmalar yapması, uyuşturucu veya uyarıcı maddenin pazarlanması, saklanması ve depo edilmesi için yer kiralaması gibi hareketler ticari maksada yönelik hareketlerdir. Keza, failin kazanç sağlamak amacıyla, sahip olduğu uyuşturucu maddelerin sevk ve naklinde kullanılmak üzere araç, donanım, eleman (kurye) temin etmesi de bu yönde hareketlerdir ${ }^{114}$.

Failin uyuşturucu veya uyarıcı madde ile ilgili reklam vermesi de mümkündür. Günümüzde internet ortamının yarattığı çevrede uyuşturucu veya uyarıcı madde satışı yapılabilmektedir ${ }^{115}$. İnternet, suçun işlenmesinde

111 Körner/Patzak/Volkmer, $\S \S 29$, Rn. 47.

112 Oğlakçıŏlu, § 29, Rn. 278.

113 Schäfer/Sander/Von Gemmeren, BtMG, Rn. 1758; Heinrich/Van Bergen, s. 323.

114 Schäfer/Sander/Von Gemmeren, BtMG, Rn. 1759; Leopald, s. 375.

115 Drugs in Cyberspace: Understanding \& Investigating Diversion \& Distribution of Controlled Substances via the Internet, http://www.cicad.oas.org/reduccion_oferta/ grupoexpertos/Farma_docs/Drugs_in_Cyberspace_Distribution_Controlled_Substances. pdf erişim tarihi 01.03.2021. 
kolaylık sağlamaktadır. Reklam, satıcının belirli koşullar altında herhangi bir kişiye uyuşturucu veya uyarıcı maddeyi teslim etmeye hazır olduğunun beyanı ve potansiyel alıcılara satın alma teklifleri sunmaları için bir davet mahiyetindedir. Esasen, böyle bir reklam satışa arz niteliğindedir. Ancak, uyuşturucu veya uyarıcı maddenin mevcut olmadığ durumlarda reklam verme uyuşturucu madde ticareti suçunun tamamlandığ 1 şeklinde yorumlanamaz ${ }^{116}$. Bu durumda şartlarının bulunması halinde TCK m. 190/2'de düzenlenen suç oluşabilir. Buna göre: "Uyuşturucu veya uyarıcı madde kullanılmasını alenen özendiren veya bu nitelikte yayın yapan kişi, beş yıldan on ylla kadar hapis ve bin günden onbin güne kadar adlî para cezası ile cezalandirtlır." (TCK m. 190/2).

Uyuşturucu maddenin henüz bulunmadığı durumlarda sonraki satışın gerçekleşmesi amacıyla pazarlık yapılması, teklif sunulması, taahhütte bulunulması veya anlaşma yapılması hazırlık hareketleri mahiyetindedir ${ }^{117}$. Bunun gibi belirsiz miktarda bir paranın ileride yapılacak uyuşturucu veya uyarıcı maddenin satın alınması için tahsis edilmesi cezalandırılmayan hazırlık hareketleri niteliğindedir ${ }^{18}$. Ancak, bir suç örgütünün faaliyeti kapsamında hazırlık hareketlerinin iş bölümü içerisinde fail tarafından yerine getirilmesi hâlinde, suçun tamamlandığ kabul edilebilir $^{119}$.

Uyuşturucu madde alım satımı değiş tokuş suretiyle de yapılabilir. Söz gelimi, eroin ile kokainin takas edilmesi mümkündür. Ticari amaçtan söz edilebilmesi için bir kazanç sağlama gayesinin bulunması gerekir. Fail, değiş tokuş ile bir ekonomik kazanç elde ediyorsa bu halde ticari amaçla bir takasın varlığından söz edilebilir ${ }^{120}$. Ancak, kazanç sağlama gayesi olmadan uyuşturucu maddenin bir başka kullanıcıya verilmesi halinde de fiil TCK $\mathrm{m}$. 188/3 kapsamında kalmaktadır.

Uygulamada sıç̧a rastlanıldığı üzere failin uyuşturucu veya uyarıcı maddenin ticareti amacıyla gizli soruşturmacının atandığı olaylarda görevlilere teklifte bulunması, uyuşturucu veya uyarıcı maddeye ilişkin numuneleri göstermesi halinde kullanma amacının bulunmadığından söz edilebilir. $\mathrm{Bu}$ durumda ticari amaçla hareket edildiğinin kabulü gerekir. Yargitay bu gibi durumlarda satımın gerçek manada bir alım satım olmadığını isabetli bir

\footnotetext{
116 Körner/Patzak/Volkmer, §§ 29, Rn. 90.

117 Körner/Patzak/Volkmer, $\S \S 29$, Rn. 54.

118 Körner/Patzak/Volkmer, $\S \S 29$, Rn. 56.

119 Körner/Patzak/Volkmer, §§ 29, Rn. 100.

120 Körner/Patzak/Volkmer, $\S \S 29$, Rn. 48, 49.
} 
biçimde kararlarında vurgulamaktadır ${ }^{121}$. Kamu görevlisinin yaptığı güven alımı gerçek bir alım satım ilişkisi niteliğinde değildir. Fail ticari maksatla uyuşturucu veya uyarıcı madde bulundurmakta, aynı zamanda bu amaçla maddeyi satışa arz etmektedir.

Faillerin suça katılımı müşterek fail şeklinde olabileceği gibi yardım etme şeklinde de gerçekleşebilir. Bu durum ceza hukukunun genel hükümlerine tabidir. Belirtmek gerekir ki suçun icra hareketlerine katkısı ile fonksiyonel hâkimiyet kuran, takım halinde ve iş bölümü esasına göre olmazsa olmaz bir biçimde katkı sağlayan failin hareketleri müşterek fail ilişkisi niteliğindedir. $\mathrm{Bu}$ anlamda aracı ve kuryenin faaliyeti bu nitelikte değilse yardım etmeden bahsedilebilir. $\mathrm{Bu}$ amaçla hareket edilmesi yeterli olup müşterek faillerin veya şeriklerin bu işten bir maddi kazanç elde etmeleri şart değildir. Aracının kendi nam ve hesabına hareket etmesi de mümkündür. Bunun yanında arka planda hareket eden, işin organizasyonunu yüklenen kişiler suçun işlenmesine müşterek fail veya azmettiren olarak katılabilirler $^{122}$.

Failin uyuşturucu veya uyarıcı madde ticareti amacıyla bir sefere mahsus hareket etmiş olması yeterlidir. Ticari faaliyetin belli bir süre devam ettirilmesi şart değildir. Münferit olayda satış, arabuluculuk ve destekleyici faaliyetlerde bulunulması mümkündür ${ }^{123}$. Keza, ticaret amacı olmadan kullanmak için uyuşturucu veya uyarıcı maddenin hediye edilmesi ya da bağışlanması TCK m. 188/3 kapsamındadır. Şayet, fail bağımlı kazanmak ve potansiyel müşteri alanı yaratmak maksadı ile hareket etmiş ise bu durumda kazanç sağlama amacının bulunduğundan bahsedilebilir ${ }^{124}$.

\section{Uyuşturucu veya Uyarıcı Maddenin Bulundurulduğu Yer ve Bulundurulma Şekli}

Yargıtay uygulamasında uyuşturucu veya uyarıcı maddenin bulundurulduğu yer ve bulundurulma şekli kullanma amacının belirlenmesinde göz

121 "Dairemizce de benimsenen Yargitay Ceza Genel Kurulunun 28/04/2015 tarihli 2014/ 462 esas, 2015/135 ve 2014/848 esas, 2015/136 sayılı kararlarında da bahsedildiği üzere; gizli soruşturmacı tarafından sanıklardan birden fazla kez uyuşturucu madde alınmasının, ayrıca suç oluşturmayacağı ve gerçek anlamda bir "alım-satım" söz konusu olmadığı gözetilmeden atılı suçların zincirleme olarak işlendiği kabul edilerek, sanıkların, cezalarının TCK'nın 43. maddesi ile artırılması suretiyle fazla ceza tayin edilmesi...". Yargitay 10. CD, 26.01.2021, 372/4160 UYAP.

122 Schäfer/Sander/Von Gemmeren, BtMG, Rn. 1761

123 Schäfer/Sander/Von Gemmeren, BtMG, Rn. 1758.

124 Körner/Patzak/Volkmer, §§ 29, Rn. 99. 
önünde bulundurulan bir diğer ölçüttür. Kullanmak için uyuşturucu madde bulunduran kişiler genellikle bu maddeleri rahatlıkla erişebilecekleri yerlerde muhafaza ederler. Maddenin ele geçirilme biçimi bu nedenle önemlidir. $\mathrm{Bu}$ anlamda uyuşturucu veya uyarıcı maddenin ayrı bir depoda, söz gelimi samanlıkta ya da depodaki balyaların altında bulundurulması halinde kullanma maksadının olmadığı ileri sürülebilir ${ }^{125}$. Keza bu madde veya maddelerin kahvehane, bar, bilardo salonu, internet kafe veya bir okul kantini işleten failin masasının çekmecesinde ele geçirilmesi halinde bulundurmanın kullanma amacı ile olmadığ kabul edilebilir. Benzer şekilde failin köylü garajı, eğlence merkezleri veya restoran gibi kalabalık ortamlara girerken veya park ve gezi yerleri, üniversite kampüsleri veya okul önünde yakalanması failin amacının belirlenmesinde göz önünde bulundurulmaktadır ${ }^{126}$.

Ele geçirilen uyuşturucu veya uyarıcı maddenin özenle hazırlanmış çok sayıda küçük paketlerden oluşması, bu maddelerin yanında paketleme makinesi, hassas terazi, tartı gibi aletlerin bulunmas1 ${ }^{127}$, bilhassa bu aletlerde uyuşturucu madde kalıntılarının tespit edilmesi ${ }^{128}$, keza uyuşturucu veya uyarıcı maddenin paketlenmesi için özel olarak hazırlanmış kâğıt parçaları, şeffaf poşet vb. malzemelerin elde edilmesi önemlidir ${ }^{129}$. Örneğin, Yargıtay

125 Yokuş Sevük, s. 414.

126 Elmas, s. 610. "Emniyet görevlilerince daha önce hakkında uyuşturucu bulundurmaktan işlem yapıldığı için bilinen ve tanınan sanığın, olay tarihinde uyuşturucu maddeyi kolaylıkla satabileceği köylü garajında yakalanması, yapılan üst aramasında montunun cebinde satışa hazır dokuz ayrı pakete sarılı esrar maddesinin bulunması, sanığın yaklaşık altı ay önce de yakalandığı yerin yakınlarında benzer şekilde satışa hazır beş ayrı pakete sarılı esrar maddesiyle yakalanmış olması göz önüne alındığında, ele geçen net olarak 9,5 gram esrar elde edilebilecek toplam 27 gram uyuşturucu maddeyi uyuşturucu madde ticareti yapma amaciyla bulundurduğu kabul olunmalıdır". Yargıtay CGK, 10.06.2014, 10-7/322 UYAP. Park yerinde yakalanan sanık için bkz: Yargitay 10. CD, 08/10/2018, 3969/6823 UYAP.

127 "Dosyadaki tüm deliller birlikte değerlendirildiğinde, sanık hakkında ihbar bulunması, ele geçen uyuşturucu maddesinin miktarı ile 2 adet dijital hassas terazininde ele geçmesi nedeniyle eylemin ticari amaçla uyuşturucu madde bulundurmak suçunu oluşturduğu, ilk derece mahkemesinin bu yöndeki kabulünün usul ve yasaya uygun olduğu...”. İstanbul BAM 5. CD, 10.02.2021, 3765/404 UYAP.

128 "İstanbul Anadolu Cumhuriyet Başsavcıllı̆̆ adli emanetinin 2014/428 sırasında bulunan uyuşturucu maddelerin paketlenmesinde kullanılan 58 adet Jamaican Gold Supreme ibareli boş paketler ve hassas terazi üzerinde, parmak izi ve uyuşturucu madde kalıntıları bulunup bulunmadığının belirlenmesi amacıyla Adli Tıp Kurumu veya uzman bir kurum ya da kuruluşa inceleme yaptırılmasından sonra sanıkların hukuki durumlarının, belirlenmesi gerekirken eksik araştırma ile hüküm kurulması...”. Yargıtay 10. CD, 11.11.2020, 616/7291 UYAP.

129 Körner/Patzak/Volkmer, $\S \S 29$, Rn. 46; “girişe göre sağ tarafta bulunan odadaki iki ayrı siyah poşet ve aynı oda içindeki minderin altında dört pakette olmak üzere toplam 
sanığın montunun sol diş cebinde bulunan poşette bir kısmı plaka, bir kısmı toz hâlinde ve ayrı ayrı şeffaf poşetler içerisindeki uyuşturucu maddenin toplam 17 parça ve her bir şeffaf poşetteki esrar gramajlarının yaklaşık aynı miktarlarda olması sebebiyle failin amacının kullanma olmadığına karar vermiştir ${ }^{130}$.

Kanaatimizce, hassas terazi ve elektronik tartı gibi araçların ele geçirilmesi her olayda ticaret amacının bulunduğu şeklinde değerlendirilmemelidir. Eroin gibi tehlikeli maddelerin tartılarak kullanılması mümkündür. Uygulamada karşılaştığımız bazı olaylarda kullanıcı şahısların bir dozda bulunması gereken miktardan fazlasını kullanmaları halinde ölüm gibi istenmeyen sonuçların gerçekleştiği görülmektedir. Yine, kullanıcıların kandırılmamak amacıyla satın alma sırasında uyuşturucu maddeyi tarttıklarını ifade ettikleri görülmektedir. Bu sebeple hassas terazinin ele geçirilmesi tek başına uyuşturucu madde ticareti suçunun işlendiğini kanıtlamaz.

Failin kastının uyuşturucu veya uyarıcı maddenin çeşitlilik arz ettiği durumlarda da denetlenmesi gerekir ${ }^{131}$. Failin üzerinde satmış olduğu uyuş-

altı parça hâlinde farklı miktarlardaki uyuşturucu maddelerin ele geçirildiği olayda; uyuşturucu maddelerin aynı oda içerisinde iki ayrı yerde ele geçirilmesi, suç konusu esrarın toplam altı parça hâlinde olması ve poşetlerde ele geçirilen esrar dışındaki diğer esrarların küçük paketçikler şeklinde iki adet folyoya, gazete kağıdına ve beyaz renkli kağıda sarılı olarak özenle hazırlanıp satışa hazır vaziyette bulundurulması karşısında; sanığın suç konusu esrarı kullanmak amacıyla bulundurduğuna ilişkin savunmasının suç ve cezadan kurtulmaya yönelik olduğu ve eyleminin uyuşturucu madde ticareti yapma suçunu oluşturduğu kabul edilmelidir”. Yargitay CGK, 20.02.2018, 10-10/57 UYAP.

130 Yargitay CGK, 22.11.2018, 10-723/562 UYAP. Benzer yönde "suç tarihinde sanık M.'in 06 DP 1804 plakalı araç ile uyuşturucu madde nakli yapacağı bilgisinin alınması üzerine durdurulan araçta, sanık M.'in eşi olan diğer sanık E.'nin üzerinden net 1,32 gram eroin, şoför koltuğunun altında 2 adet poşet içerisinde toplam net 8,79 gram eroin ve aracın ön konsol orta kısmında bulunan sigara küllüğü içerisinde net 0,14 gram eroin ele geçirildiği anlaşılmakla; uyuşturucu maddelerin edinilen bilgiyi doğrulayacak şekilde ele geçirilmesi, miktarı, farklı yerlerde ve ayrı ayrı paketler halinde olması hususları birlikte değerlendirildiğinde, ticari amaçlı uyuşturucu madde bulundurduğu anlaşılan sanı ğın atılı suçtan mahkumiyeti yerine, yerinde olmayan gerekçe ile yazılı şekilde beraatine karar verilmesi...”. Yargitay 10. CD, 20.01.2021, 3065/733 UYAP.

131 "Olay tarihinde saat 16.15 sıralarında, İzmir 3. Sulh Ceza Hakimliğinin 2014/1887 D. İş Nolu Arama ve El Koyma kararına istinaden sanığın ikametinde yapılan aramada 59 adet yeşil renkli, 18 adet sarı renkli olmak üzere toplam 77 adet ecstasy hap ve daralı ağırlığı 110 gr esrar ele geçirilmesi karşısında; suça konu uyuşturucu maddelerin miktarı, çeşitliliği, ele geçirildiği yer ve dosya içeriğine göre; sanığın eyleminin uyuşturucu madde ticareti yapma suçunu oluşturduğu gözetilmeden, suç vasfinın tayininde yanılgıya düşülerek kullanmak amacıyla uyuşturucu madde bulundurma suçundan mahkûmiyetine karar verilmesi...”. Yargitay 10. CD, 03.12.2019, 2913/7617 UYAP. 
turucu maddeden farklı bir madde ele geçirilmiş olabilir. Söz gelimi, metamfetamin sattığı tespit edilen failin üzerinde sentetik kannabinoid yakalanmış olabilir. Bu durumda sentetik kannabinoidinin satmak amacıyla bulundurulduğuna dair başkaca delil yoksa kişisel kullanım sınırındaki bu maddenin taşınması ticari amaçla bulundurma olarak kabul edilemez ${ }^{132}$. Yargitay'ın da isabetli bir biçimde vurguladığ 1 üzere uyuşturucu veya uyarıcı maddelerin çeşitlilik göstermesi tek başına yeterli değildir. Failin bu maddeleri kullanma amacı dışında bulundurduğu başka delillerle de ispatlanmalidir ${ }^{133}$.

\section{Uyuşturucu veya Uyarıcı Madde Kullanma Alışkanlığı}

Karşılaştırmalı hukukta olduğu gibi Yargıtay kararlarında failin uyuşturucu veya uyarıcı madde kullanma alışkanlığı; satın alma, kabul etme veya bulundurma amacını ortaya koymak bakımından önemlidir. Fail hakkında uyuşturucu madde kullanması sebebiyle soruşturma yapılması, hakkında tedbire hükmedilmesi, failin uyuşturucu madde bağımlısı olması uyuşturucu veya uyarıcı maddenin kullanma amacıyla satın alındığı, kabul edildiği veya bulundurulduğuna delil teşkil edebilir ${ }^{134}$. Bu anlamda failin kan ve idrar tetkiklerinde uyuşturucu veya uyarıcı madde kullanımına ilişkin bulguya rastlanması kullanma amacının varlığına yönelik bir delildir ${ }^{135}$.

132 "Sanığın 20/10/2017 tarihinde hakkında kullanmak için uyuşturucu madde bulundurma suçundan işlem yapılan O. K. K.'a, 26/10/2017 tarihinde de hakkında kullanmak için uyuşturucu madde bulundurma suçundan işlem yapılan S. Ö.’e suç konusu metamfetamin maddelerini sattığı sabit ise de; üzerinde yapılan aramada ele geçirilen tek parça halinde 0,03 gramdan ibaret sentetik kannabinoidi ticari amaçla bulundurduğu konusunda her türlü şüpheden uzak kesin delil bulunmadığı gözetilmeden sanık hakkında TCK'nın 188/4-a maddesinin uygulanması suretiyle fazla ceza tayini...”. Yargitay 10. CD, 08/05/2019, 935/2557 UYAP.

133 "Suça konu esrarın dışında, sanığın evinde yapılan aramada 0,07 gram miktarda TCK'nın 188/4 maddesi kapsamında sentetik kannabinoid ele geçirildiğinin anlaşılması karşısında, sanığın sözü edilen maddeyi hangi amaçla bulundurduğunun araştırılması, ticari amaçla bulundurduğunun tespit edilmesi halinde ise sanık hakkında TCK'nın 188. maddesinin 4. fikrası da uygulanmak suretiyle hüküm kurulduktan sonra...”. Yargitay 10. CD, 18/09/2017, 691/3799 UYAP.

134 Özbek/Doğan/Bacaksız, s. 815; Günal, Yılmaz, "Uyuşturucu Madde Kullanma Suçları”, Ankara Üniversitesi SBF Dergisi, Cilt: 32, Sayı: 01, Ocak 1977, s. 71.

135 "sanığın evinde yapılan aramada kullanım sınırları içerisinde bulunan net 2,4 gr olan esrar ele geçirildiği ve yapılan tahlilde uyuşturucu maddeye rastlandığı da sabit olmakla sanığın eyleminin kullanmak için uyuşturucu madde bulundurma suçunu oluşturacağı gözetilmeden yazılı şekilde hüküm kurulması...”. Yargıtay 10. CD, 06/10/2020, 1266/ 4973 UYAP; "Mahkemece sübut kabul edilerek sanık S. Y. hakkında zincirleme suç hükümlerinin uygulanmasına esas alınan 27/11/2016 tarihli eylemle ilgili olarak, gerek 
Kanaatimizce, failin kullanma alışkanlığı ve sıklığı somut olayın özelliklerine göre değerlendirilmelidir. Bağımlı bir kişinin kullanma sıklığı ile kullanım miktarı ara sıra veya ilk kez uyuşturucu veya uyarıcı madde kullanan kişiler ile farklılık gösterecektir. Başkaca bir delilin bulunmadığı durumlarda failin madde bağımlılığ kullanma amacı lehinde bir durum olarak değerlendirilmelidir. Keza, karşılaştırmalı hukukta öngörülen ve ilk defa veya ara sıra uyuşturucu madde kullanan kişiyi esas alan bir düzenlemeye hukukumuzda rastlanmamaktadır. Dolayısıyla, failin kullanma alışkanlığının dikkate alınması gerekir. Objektif ve mutat kullanıcı esas alınarak bir belirleme yapmak yerine somut olayın koşulları çerçevesinde sübjektif bir değerlendirme yapılmasında yarar vardır.

\section{E. Failin Ekonomik Durumu}

Failin ekonomik durumunda hareketlilik görülmesi uyuşturucu veya uyarıcı maddenin hangi amaçlarla satın alındığı, kabul edildiği veya bulundurulduğu hususunu değerlendirmede yardımcı olabilir. Failin ekonomik durumunda normalin dışında hesap hareketlerinin bulunması, failin harcama eğiliminde radikal değişiklikler meydana gelmesi ticari amacın varlığına delil teşkil edebilirr ${ }^{136}$. Bu anlamda failin daha önce uyuşturucu veya uyarıcı madde ticareti yapma suçundan hükümlü olup olmadığ 1 ve failin geçimini ne ile sağladığı da önemlidir ${ }^{137}$.

Kanaatimizce bu kriter, diğer kriterler gibi failin cezalandırılması için tek başına yeterli değildir. Failin mal varlığındaki anormal artış, harcama eğilimindeki radikal değişiklikler başka suçların işlenmesi sebebiyle de gerçekleşebilir. Keza, failin daha önce uyuşturucu madde ticaretinden mahkûm edilmiş olması her zaman maddi gerçeklik ile uyumlu olmayabilir. Her somut olayın kendine has özellikleri bulunduğundan ispat araçlarının buna göre takdir edilmesi gerekir.

Yargıtay uygulamasında uyuşturucu veya uyarıcı maddenin değeri failin ekonomik durumu ile bağlantılı olarak dikkate alınmaktadır. Failin aylık

kendi beyanı gerekse kan-idrar tahlili ile bilimsel olarak esrar kullandığı saptanan sanığın, diğer sanık Adnan ile birlikte Kahta ilçesine giderek temin ettiği 470 gram (net 170 gram) esrarı satacağı ya da başkalarına vereceği ya da ticari amaçla temin ettiği/bulundurduğu/naklettiği hususunda tape içeriklerinde açı/örtülü herhangi bir ibare veya dosyada savunmanın aksini kanıtlayan delil mevcut olmadığ gözetilmeden anılan eylem esas alınarak sanığın cezasında zincirleme suç nedeniyle artırım yapılarak fazla ceza tayini...". Gaziantep BAM 5. CD, 11.02.2021, 844/232 UYAP.

136 Yokuş Sevük, s. 412.

137 Elmas, s. 613. 
geliri ile orantılı miktarda uyuşturucu veya uyarıcı madde satın alması diğer delillerle birlikte failin kullanma amacının değerlendirilmesinde gözetilmektedir. Dolaylı da olsa kararlarda uyuşturucu veya uyarıcı maddenin piyasa değerine atıf yapılmaktadır ${ }^{138}$. İngiltere'de, narkotik maddenin sokak satış değerine önem verilmektedir. Özellikle 1994 y1lından önce mahkemelerin esas aldığı temel kriter bu değerdi. Son dönemde etkisi azalmasına rağmen, mahkeme kararlarında bu değere vurgu yapılmaktadır. Sokak değeri; ele geçirilen uyuşturucu maddenin miktarı, saflığı ile ortalama aynı nitelikte bir maddenin saflık değeri ve ortalama fiyatının karşılaştırılması suretiyle denetlenmektedir ${ }^{139}$.

Failin ekonomik durumu ve uyuşturucu veya uyarıcı maddenin miktarı ile bağlantılı olarak ele geçirilen maddenin piyasa değerinin gözetilmesi mümkündür. Miktarın yüksek olduğu veya failin ekonomik durumu ile uyumsuz olduğu hallerde ticari bir maksatla hareket edildiği yönünde bir değerlendirme yapılabilir. Ancak, sokak değeri her zaman sağlıklı sonuçlar vermeyebilir. Niteliği gereği konusu suç teşkil eden bir alım satımın veya

138 Körner/Patzak/Volkmer, $\S \S 29$, Rn. 66; “21.01.2014 tarihinde saat 02.45 siralarında Narkotik Suçlarla Mücadele Şube Müdürlüğü görevlilerince İncirlik park alanındaki uygulama noktasına gelen Van Erciş Seyahate ait otobüsün durdurulduğu, otobüste yapılan kontrollerde otuz beş numaralı koltukta yolculuk yapan sanı̆̆ın yanındaki poşet ile birlikte otobüsten indirildiği, söz konusu poşete bakıldığında içinde esrar olduğunun görüldügüü, ardından görevlilerce yapılan üst yoklamasında sanığın pantolonunun arka cebinde sekiz adet hapın ele geçirildiği olayda; sanıkta iki farklı nitelikte uyuşturucu madde ele geçirilmesi, aylık gelirinin 1200 Lira olduğunu beyan eden sanı̆̆ın neredeyse gelirinin yarısına yakın bir miktar olan 450 Liraya suç konusu uyuşturucu maddeleri alması, Gaziantep’ten Manavgata'a giden sanı̆̆ın, içerisinde suç konusu esrarın ele geçirildiği poşet dışında herhangi bir kişisel eşyasının bulunmaması, bu hususun tanık E.'ın beyanı ve olay tutanağı içeriği ile doğrulanması, sanığın amfetamin etken maddesi içeren haplardan iki tanesini kullandığını beyan etmesine rağmen kanında ve idrarında yapılan incelemede esrar etken maddesinin tespit edilmesi birlikte değerlendirildiğinde; ele geçirilen suç konusu uyuşturucu maddelerin sanık tarafından kullanma dışındaki bir amaçla nakledildiği, sanığın söz konusu uyuşturucu maddeleri kullanmak için Manavgat'a götürdüğüne ilişkin savunmasının kendisini suç ve cezadan kurtarmaya yönelik olduğu anlaşıldığından sanığın sabit görülen eyleminin uyuşturucu madde ticareti yapma suçunu oluşturduğu kabul edilmelidir”. Yargitay CGK, 24.04.2018, 20-208/182 UYAP.

139100.000 Sterlin veya daha fazla değerde bir uyuşturucu maddenin ele geçirilmesi halinde asgari ceza yedi y1l; 1.000 .000 Sterlin veya daha fazla değerde sokak değerine sahip uyuşturucu madde ele geçirilmesi halinde ise asgari 12 ila 14 yıl arasında bir hapis cezası uygulanmaktaydı. Izenman, Alan J.: "Sentencing Illicit Drug Traffickers: How Do The Courts Handle Random Sampling Issues?”, International Statistical Review, Volume: 71, No: 3 (December 2003), s. 536. 
tedarikte bulunmanın gerçek bir piyasa değerinden bahsetmek mümkün değildir. Bu durum kişiden kişiye, bölgeden bölgeye farkl1l1klar gösterebilir.

\section{F. Uyuşturucu veya Uyarıcı Maddenin Miktarı}

Uyuşturucu veya uyarıcı maddenin miktarının fazlalı̆̆ karşılaştırmalı hukukta, bazı ülkelerde daha ağır bir biçimde cezalandırmayı gerektiren bir nitelikli hal olarak kabul edilmiştir. Bulgaristan, Çek Cumhuriyeti, Danimarka, Almanya, İspanya, Yunanistan, Macaristan, Avusturya, İsveç ve İngiltere bu duruma örnek gösterilebilir. Bunun yanında madde miktarı Alman veya Avusturya hukukunda suçun tipikliğine dâhil bir unsurdur ${ }^{140}$.

Hukukumuzda ise böyle bir nitelikli hal bulunmamaktadır. Kanun koyucu, uyuşturucu maddenin türüne göre bir nitelikli hal kabul etmiştir. Maddenin miktarı ise cezanın bireyselleştirilmesinde dikkate alınmaktadır. Uygulamada uyuşturucu veya uyarıcı maddenin miktarının fazla olduğu hallerde ceza miktarı asgari hadden ayrılmak suretiyle belirlenmektedir.

Kanaatimizce, kanun koyucunun madde miktarını suçun bir unsuru veya cezayı ağırlaştıran nitelikli bir hal olarak öngörmemesi yerindedir. Madde miktarı kişisel kullanım ile bağlantılı olduğundan kişiden kişiye farklılık arz edebilir. Kişisel kullanım amacının belirlenmesinde kişinin ruhsal ve fiziksel özellikleri, uyuşturucu veya uyarıcı maddenin niteliği, cinsi ve kalitesi göz önünde bulundurulmalıdır. Bunun tespiti ise soruşturma ve kovuşturma ile görevli makamlara aittir.

Yargıtay uygulamasında kişisel kullanım miktarı ile ilgili doğrudan bir tespite rastlanılmamaktadır. İzinsiz Hint keneviri ekme suçu ile ilgili kök sayıs1 itibarıyla bir belirleme yapılmasına rağmen, TCK m. 188/3 bakımından böyle bir durum söz konusu değildir ${ }^{141}$. Ancak, Yargitay kararlarından hareketle uyuşturucu veya uyarıcı maddenin türü ve miktarı ile ilgili bazı açıklamalarda bulunulabilir.

140 Lai, Gloria: Drugs, Crime and Punishment, Series on Legislative Reform of Drug Policies, Nr. 20, June 2012, http://fileserver.idpc.net/library/Drugs-crime-andpunishment-Proportionality-of-sentencing\%20(1).pdf erişim tarihi 15.03.2021.

141 "Olay tutanağı içeriğine, dosyadaki diğer bilgi ve belgelere göre, sanığın ikametinin bahçesine sanık tarafından ekilmiş halde bulunan 386 kök kenevirden olgunlaştıklarında elde edilecek esrarın, kişisel kullanımı için gerekli miktardan fazla olacağı, Dairemizin genel uygulamalarına göre, ticari amaçla ekildiklerine ilişkin başka delil yoksa 20 köke kadar dikili kenevirin kişisel kullanım kapsamında ekildiğinin kabul edilebileceği dikkate alınarak, sanığın eyleminin 2313 sayılı Yasanın 23/5. maddesinin 1. cümlesi kapsamında kalan esrar elde etmek amaciyla kenevir ekme suçunu oluşturduğunun kabulü gerektiğinin gözetilmemesi...”. Yargitay 10. CD, 01.10.2020, 5379/4735 UYAP. 
Yargıtay kararlarında kişisel kullanım amacının belirlenmesinde, kesin bir ölçüt olmamakla beraber, ortalama olarak bir kişinin kullanabileceği bir doz esrar miktarının 0.5 gram ve günlük doz sayısının en fazla 4 ila $6 \mathrm{doz}$ olduğu ifade edilmiştir. Bir doz eroin miktarının $10 \mathrm{mg}$ ve günlük doz say1sının ise 4 ile 6 arasında olabileceği, buna göre ortalama bir insanın bir günde tüketebileceği esrar miktarını 3 gram, eroin miktarının ise $60 \mathrm{mg}$ olduğu belirtilmiştir ${ }^{142}$. Bu miktarlar ele geçirilen maddenin daralı ağırlığ 1 yerine içerdiği etken madde itibarıyla belirlenmelidir. Buna göre maddenin net miktarları üzerinden kişisel kullanım sınırı tespit edilmelidir ${ }^{143}$. Ancak, daralı ağırlığın Yargıtay kararlarında tamamıyla göz ardı edildiğinden söz edilemez. Diğer delillerle birlikte buna da önem verilmektedir ${ }^{144}$.

Konu ile ilgisi bakımından bir hususun açıklanmasında fayda vardır: Bazı uyuşturucu maddeler hakkında miktara bağlı analiz yapılamamaktadır.

142 "Merkez Jandarma Kriminal Laboratuvar Amirliği tarafından hazırlanan 17/08/2017 tarihli uzmanlık raporunda, sanıktan ele geçirilen toplam 24,2 gram maddenin $\% 6,2$ oranında eroin ve \%1,16 oranında 6-MAM içerdiği belirtilmiş̧tir. Buna göre; sanıktan elde edilen uyuşturucu maddenin 1,50 gramı eroin, 0,28 gramı ime 6-MAM maddesidir. Eroin maddesi, Yargıtay'ın genel uygulamaları nazara alındığında sanığın 25 günlük ihtiyacını karşılamaya yetecek miktardadır”. Adana BAM 5. CD, 09/05/2018, 811/1126 UYAP.

143 'Mersin'de ikamet eden sanığın, Diyarbakır'dan Antalya'ya gitmekte olan yolcu otobüsüne Diyarbakır'da bindiği, önleme arama kararı üzerine otobüsün Birecik ilçesinde durdurulup arandığı ve 41 numaralı koltukta oturan sanığa ait iki çanta içinde toplam net 748 gram esrarın ele geçirildiği; sanığın bu esrarı kullanmak için Diyarbakır'da bir kişiden satın aldığını söylediği anlaşıldığından; Yeni Diyarbakır firması kayıtlarından, sanığın olay günü bulunduğu otobüs için aldığı biletin araştırılması, varsa aslı veya onaylı örneğinin getirtilmesi; a) Sanık Mersin dışında bir yere gitmek için bilet almış ise, fiilinin "satmak amacıyla uyuşturucu madde bulundurup nakletme", b) İkamet ettiği Mersin'e gitmek için bilet almış ise, savunmasının aksine delil olmadğı gözetilip sanığın fiilinin "kullanmak için uyuşturucu madde bulundurma" suçunu oluşturacağı dikkate alınarak sanığın hukukî durumunun belirlenmesi gerekirken, eksik araştırma ile ve esrar miktarı 3640 gram kabul edilerek hüküm kurulması...”. Yargıtay 10. CD, 19.06.2015, 2434/31825 UYAP.

144 "Olay tarihinde sanığın adresinde yüklü miktarda esrar sakladığı ve bu esrarı torbacı diye tabir edilen kişilere satacağı yönünde muhbirden bilgi alınması üzerine ikamette yapılan aramada bir adet siyah ve bir adet kırmızı poşet içinde toplam daralı ağırlığı 1330 gr esrar ele geçirilmesi ile ilgili olarak, sanık soruşturma aşamasında alınan beyanlarında evine gelen misafirin bıraktığı poşet olduğunu beyan ederken, mahkemede alınan savunmasında kullanmak için aldığını beyan etmiş ise de; suça konu uyuşturucu maddenin miktarının fazlalığı, başkalarına kolayca teslim edilmeye hazır 2 ayrı poşete konulmuş halde bulundurulması ve dosya içeriğine göre; sanığın eyleminin uyuşturucu madde ticareti yapma suçunu oluşturduğu gözetilmeden, suç vasfinın tayininde yanılgıya düşülerek kullanmak amaciyla uyuşturucu madde bulundurma suçundan mahkûmiyetine karar verilmesi...”. Yargitay, 10. CD, 11.07.2019, 2051/5139 UYAP. 
Söz gelimi, kriminal raporlarda, ele geçirilen uyuşturucu maddenin içeriğine göre sentetik kannabinoidler grubunda olduğu belirtilmekte, miktarı tespit edilememektedir. Bu sebeple miktardan ziyade failin hangi amaç ile hareket ettiğinin belirlenmesi gerekir.

Miktar bakımından uyuşturucu maddenin daralı ağırlı̆̆ı ile içeriğindeki etken maddenin birlikte değerlendirilmesinde yarar vardır. Etken madde içeriği her zaman sağlıklı sonuçlar vermeyebilir. Nihayetinde kimyasal ve sentetik maddeler laboratuvar ortamında analiz edilerek belirlendiğinden bu durum kullanıcılar tarafindan denetlenememektedir. Uygulamada yakalanan uyuşturucu maddeler ile içeriğindeki saf miktarlar arasında ciddi farklar gerçekleşebilmektedir. Söz gelimi, 1 kilogram Hint kenevirinden 300 veya 400 gram esrar elde edilebileceğine; 10 gram eroinin içerdiği net miktarın 2 veya 3 gram olabileceğine kriminal raporlarda rastlamaktayız.

Yargıtay önceki uygulamalarında kişisel kullanım miktarının belirlenmesinde "1 y1llık kullanım miktarını" esas almaktayd $1{ }^{145}$. Son yıllarda verilen kararlarda bu ölçüt yerine somut olayın özelliklerine göre belli bir zaman dilimi içinde sanık tarafından tüketilebilecek miktar esas alınmaktadır ${ }^{146}$.

Uyuşturucu veya uyarıcı maddeler için yıllık kullanım miktarının aranması her zaman isabetli sonuçlar vermeyebilir. Keza, her bir uyuşturucu veya uyarıcı madde bakımından net bir miktarın öngörülmesi de mümkün değildir. Kişiye bağlı olarak kullanım miktarları değişebilir. Bunun yanında Yargıtay kararlarında işaret edildiği üzere, söz gelimi, esrar için günlük 4,5 grama kadar kullanımın mümkün olabileceği ifade edilmiştir. Bu hesaba göre aylık kullanılması muhtemel esrar miktarı 135 gram olup bu da yıllık 1500 gram gibi bir rakama denk gelmektedir. Bu miktarda bir esrarın yakalanması halinde Yargıtay fiili, uyuşturucu veya uyarıcı madde ticareti olarak kabul etmektedir. Dolayısıyla madde miktarı itibarıyla yıllık tüketim miktarı şeklinde bir tespitin yapılmaması ve önceki içtihatlardan dönülmesi yerindedir.

145 Özbek/Doğan/Bacaksız, s. 816; “Aracında yapılan arama sonucu ele geçen kenevir bitkisi dışında, sanığın uyuşturucu madde ticareti yaptığı yolunda başka bir kanıtın elde edilememesi, uygulamada kabul edilen günlük kullanım miktarı dikkate alındığında, ekspertiz raporunda belirtilen üçyüzkırk gramlık uyuşturucu madde miktarının yıllık kişisel kullanım sınırları içerisinde bulunması, sanığın söz konusu uyuşturucu maddeyi satmak için değil kullanmak amacıyla bulundurduğu yönündeki aksi kanıtlanamayan savunmaları birlikte değerlendirildiğinde, uyuşturucu veya uyarıcı madde ticareti suçunu işlediği kuşku boyutunda kalmaktadır”. Yargıtay CGK, 26.06.2012, 10-294/253 UYAP. 
Uygulamada kişisel kullanım miktarının belirlenmesinde failin ikametinden ayrıldığı, şehir dışına çıktığı hallerde orada geçireceği süre dikkate alınmaktadır. Söz gelimi, Yargıtay bir haftalık tatil için 10 gram eroin maddesini üzerinde bulunduran failin amacının kullanma olmadığına, failin bulundurduğu miktarın tüketmesi muhtemel miktarın çok üzerinde olduğuna karar vermiştir ${ }^{147}$. Keza, failin kullanmak için uyuşturucu veya uyarıcı madde ile satın almanın gerçekleştiği veya ikamet ettiği şehir dışında başka bir yerde yakalanması Yargitay kararlarında dikkate alınmaktadır. Failin başka bir şehirde yakalanmış olması kazanç sağlama amacının bulunduğuna delil teşkil etmektedir ${ }^{148}$.

Failin başka bir şehirde yakalanmış olması her somut olayda farklı bir biçimde ele alınmalıdır. Sadece bu iki yer dışında bir yerde bulunma tek başına manevi unsurun belirlenmesinde yeterli değildir. Diğer delillerle birlikte ticari amacın bulunup bulunmadığ 1 denetlenmelidir.

Uyuşturucu maddenin miktarının tereddüde yer vermeyecek şekilde fazla olması halinde Yargıtay kullanma amacının bulunmadığına karar vermektedir. Bu durumda failin kullanıcı olmasının bir önemi yoktur. Kişisel tüketim miktarı içerisinde bir maddenin de somut olayın özelliklerine göre ticari maksatla bulundurulduğu kabul edilebilir. Söz gelimi, evinde 3 gram eroin ele geçirilen failin fiili, kullanmak için uyuşturucu madde bulundurmak olarak kabul edilebilir. Şayet, aynı miktarda madde bir eğlence mekânında ele geçirilmiş ise TCK m. 188/3 kapsamında görülebilir. Keza, gelir

147 "Olay tarihinde, sanığın sevk ve idaresindeki araç içerisinde yapılan aramada, aracın sol ön kapı gözünde darasız ağırlı̆g 1 4,14 gram toz esrar ve cam kavonoz içerisinde daralı ağırlığı 239,96 gram esrar ile üzerinde daralı ağırlığ 2,25 gram esrarın ele geçirilmesi ve sanığın olay tarihinden bir hafta önce aldığını belirttiği bu suç konusu uyuşturucu maddeleri günlük ihtiyacından çok fazla olacak şekilde aracında bulundurması karşısında, eyleminin ticaret amaciyla uyuşturucu madde bulundurma suçunu oluşturup oluşturmadığına ilişkin delilleri tartışma ve değerlendirme görevinin üst dereceli Ağır Ceza Mahkemesine ait olduğu gözetilip, görevsizlik kararı verilmesi gerekirken, yargılamaya devamla hüküm kurulması...". Yargitay 10. CD, 15.01.2019, 4862/314 UYAP.

148 "Sanığın üst aramasında, pantolonunun bel kısmında, kemer ile beli arasına sıkıştırılmış vaziyette üç adet streç film ile sarılı net ağırlığ 595 gram toz esrar ele geçirilmesi karş1sında; suç konusu uyuşturucu maddenin kişisel kullanım miktarının üzerinde olması, bulundurulma şekli, ele geçiriliş biçimi, sanığın yakalandığı yer ve zaman ile Bingöl ili Genç ilçesi Yayla köyünde ikamet eden sanığın, Bingöl'den kullanmak için aldığını iddia ettiği esrar ile Diyarbakır ili Sur ilçesinde yakalanmış olması dikkate alındığında, sanığın bu maddeleri başkalarına verme amacı ile bulundurduğu açık olup, eyleminin uyuşturucu madde ticareti yapma suçunu oluşturduğu gözetilmeden, suçun niteliği yanlış değerlendirilerek kullanmak için uyuşturucu madde bulundurma suçundan hüküm kurulmas1...”. Yargitay 10. CD, 26.02.2020, 4767/1384 UYAP. 
düzeyi yüksek olan failin evinde 15-20 gram eroin ele geçirilmesi halinde bu miktar kişisel kullanım sınırında değerlendirilebilir. Bu durumda failin ekonomik durumu ve madde miktarı birlikte ele alınarak bir kanaate varılmalidir ${ }^{149}$.

Bir Yargitay kararında " üst yoklamasında ayrı ayrı şeffaf poşetlerde, satışa hazır ve 17 parça hâlinde esrar ele geçirilen sanığın, uyuşturucu madde kullandı̆̆ının teknik yöntemlerle de saptanmadı̆̆g dikkate alındlğında, suç konusu uyuşturucu maddeleri içmek için bulundurduğuna yönelik savunmasının, uyuşturucu madde ticareti yapma suçunu gizlemeye ve bu suçun cezasından kurtulmaya yönelik olduğunun, bu bağlamda kullanmak için uyuşturucu madde bulundurma suçunun sübut bulmadı̆̆ının kabulü..." gerektiği ifade edilmiştir ${ }^{150}$. Yargitay, çok sayıda uyuşturucu madde paketiyle failin yakalandığı bu olayda sanığın uyuşturucu madde kullandığına dair bir bulgu elde edilememesi nedeniyle fiili, TCK m. 188/3 kapsamında kabul etmiştir.

Kanaatimizce, uyuşturucu maddenin gramaj olarak eşit veya birbirine yakın paketler halinde olması halinde somut olayın özelliklerine göre bir değerlendirme yapılmalıdır. Uygulamada gördüğümüz bazı davalarda, satıcı şahısların fişek veya paket halinde satışa sundukları uyuşturucu maddelerden kişisel kullanımı için satın alan faillerin, sadece çok sayıda fişek veya paket ile yakalanması, her zaman ticari amaçla hareket edildiğini ortaya koymamaktadır. Başka delillerin bulunmaması halinde şüpheden sanık yararlanır ilkesi gereğince karar verilmelidir ${ }^{151}$. Şayet ele geçirilen fişek veya paket

149 “18.11.2006 tarihinde polis ihbar hattına sanığın İstanbul'dan Tekirdağ ili Çorlu ilçesine 34 EE 128 plakalı araçla esrar ve eroin getireceğine dair ihbar yapılması üzerine araç durdurularak yapılan aramada sanığın iç çamaşırının içine gizlenmiş halde net ağırlığı 50 gr kokain ve sanığın evinde yapılan aramada televizyon üstünde bulunan süs eşyası içinde net ağırlığı 04. gr kokain ile cam şişe içinde amonyak ele geçirilmesi karşısında; sanığın üzerinde ele geçen suç konusu uyuşturucu maddenin miktarı, bulundurulma şekli ve ele geçiriliş biçimi dikkate alındığında, sanığın bu maddeleri başkalarına satma amacı ile temin ettiğinin anlaşılması karşısında, eyleminin uyuşturucu madde ticareti yapma suçunu oluşturduğu gözetilmeden, suçun niteliği yanlış değerlendirilerek kullanmak için uyuşturucu madde bulundurma suçundan hüküm kurulması...”. Yargıtay 10. CD, 22.01.2020, 4190/517 UYAP; “03.09.2008 tarihli tutanak içeriği, uyuşturucu maddenin ele geçirildiği yer, net ağırlığı 1710 gram olan suça konu esrarın kişisel kullanım gereksiniminin çok üzerinde olmasına ve dosya kapsamına göre, sanığın eyleminin uyuşturucu madde ticareti yapma suçunu oluşturduğu gözetilmeden suçun niteliği yanlış değerlendirilerek kullanmak için uyuşturucu madde bulundurma suçundan hüküm kurulmas1...". Yargitay 10. CD, 13/11/2018, 4310/7960 UYAP.

150 Yargitay CGK, 22.11.2018, 10-723/562.

151 Meydan, s. 336; "Sanı̆̆ın uyuşturucu madde ticareti yaptığına ilişkin şüpheden uzak kanıt bulunmadığı, polisler geldiğinde cep telefonunu atmasını, cep telefonu ele geçirilip 
adedi ve miktarı tereddüde yer vermeyecek bir biçimde fazla ise bu durumda ticari amacın bulunduğundan söz edilebilir. Nitekim Yargıtay bu yönde, failden elde edilen ve bilirkişi raporuna göre 5,81 gram olduğu tespit edilen 22 adet fişek halde esrarın tek başına kullanma amacı dışında bir amaçla bulundurulduğu şeklinde değerlendirilemeyeceğine karar vermiştir ${ }^{152}$.

Yargıtay, failin uyuşturucu maddenin bir kısmını kullanmak için ayırdığ 1 durumlarda bu miktarı toplam miktardan ayrı değerlendirmektedir ${ }^{153}$. Yargitay bu durumda sanık lehinde bir değerlendirme yapmaktadır.

Fail uyuşturucu maddeyi başlangıçta ticari maksatla satın almış ve daha sonra bu miktardan bir kısmını kullanımı için ayırmış ise failin toplam miktar üzerinden sorumlu tutulması gerekir ${ }^{154}$. Failin sonraki kastı ile kullanmak amacıyla bir miktar maddeyi ayırması, sonucu değiştirmemektedir.

içerikleri tespit edilemediğinden sanığın uyuşturucu madde ticareti yaptığına ilişkin suçun subutuna etki edebilecek kanıt olarak değerlendirilemeyeceği, sanığın birbirine eşit paketler halindeki uyuşturucu madde bulundurmasının başlı başına maddeleri ticari amaçla bulundurduğu sonucunu doğurmayacağı, kişisel kullanım için alınan maddelerin de satan kişi tarafından genellikle eşit paketler halinde satılmasının bilinen bir gerçek olduğu, sanıkta ele geçen uyuşturucu maddelerin bilinen piyasa değeri miktarının aylık kazanç miktarının üzerinde olmaması, herhangi bir kimseye uyuşturucu madde verdiğinin tespit edilememiş olması, soruşturmayı başlatan ihbar içeriğinden sanıkların araç içinde uyuşturucu madde kullandıklarının bildirilmiş olması, uyuşturucu madde sattıkları veya satmak amacı ile bulundurduklarına ilişkin herhangi bir ihbarın bulunmaması göz önüne alındığında...”. Trabzon BAM 3. CD, 25.02.2021, 82/350 UYAP.

152 "Suç konusu uyuşturucu maddelerin sanığın ailesi ile birlikte ikamet ettiği evinde ele geçirilmesi, sanık ile birlikte evde kalan diğer kişilerce de kolaylıkla erişebilecek bir yer olan, girişe göre sağdan ikinci odadaki sobanın üzerinde bulunan minderlerden birisinin arasındaki poşette (22) fişek hâlinde bulunması, net toplam 5,81 gram ağırlığında olan esrarın miktarı itibarıyla kişisel kullanım sınırları içerisinde kalması, uyuşturucu maddenin ele geçirildiği yerde veya yakınında, hassas terazi veya paketlemede kullanılan ambalaj malzemeleri vb. materyallerin bulunmaması, sanığın söz konusu esrarı başkasına satma, devir veya tedarik etmek hususunda herhangi bir davranış içine girdiğine ilişkin dosya kapsamı itibarıyla herhangi bir somut delilin elde edilememesi, tanık A.'nin sanığın uyuşturucu madde kullandığını ancak satmadığını beyan etmesi, sanığın da savunmalarında ele geçirilen uyuşturucu maddeleri kullanmak amaciyla bulundurduğunu, olaydan bir gün önce ele geçirildiği şekilde satın aldığını savunması hususları birlikte değerlendirildiğinde; ele geçirilen suç konusu uyuşturucu maddelerin sanık tarafından kullanma dışındaki bir amaçla bulundurulduğuna ilişkin, sanığın savunmasının aksine, soyut istihbarat bilgisi dışında kuşkuyu aşan, kesin ve yeterli delil bulunmadığı anlaşıldığından, sanığın sabit görülen eyleminin bir bütün hâlinde kullanmak için uyuşturucu madde bulundurma suçunu oluşturduğu kabul edilmelidir”. Yargitay CGK, 19.03.2019, 10-476/218 UYAP.

153 Oğlakçıoğlu, § 29, Rn. 72.

154 Oğlakçıoğlu, $\S 29$, Rn. 76. 
Birden fazla uyuşturucu veya uyarıcı madde kullanıcısının kişisel kullanımları için daha büyük bir miktarda madde alarak daha düşük fiyattan yararlanmak istemeleri halinde ortak bir biçimde satın almanın ticaret olarak değerlendirilmemesi gerekir ${ }^{155}$. Bu yönde, Yargıtay ele geçirilen uyuşturucu maddenin kişisel kullanım sınırının belirlenmesinde sanık sayısının gözetilmesine karar vermiştir ${ }^{156}$.

Faillerin iştirak ilişkisi içinde hareket ederek suçtan kurtulmak maksadıyla, fail sayısınca ve kullanım sınırında kabul edilebilecek miktarda uyuşturucu veya uyarıcı maddeyi sevk veya nakil etmeleri mümkündür. $\mathrm{Bu}$ durumda diğer delillerle birlikte ve somut olayın koşulları çerçevesinde bir değerlendirme yapılmalıdır. Aksi halde, şüpheden sanık yararlanır ilkesi gereğince TCK m. 191 uyarınca hüküm kurulmalıdır.

\section{SONUÇ}

Uyuşturucu veya uyarıcı madde imal ve ticareti suçu kasten işlenebilen suçlardandır (TCK m. 188). Suçun taksirle işlenmiş hali Kanun'da düzenlenmemiştir. Doktrinde kabul edildiği üzere suçun olası kast ile işlenmesi mümkündür. Benzer şekilde TCK m. 191'de düzenlenen suç kasten işlenebilen bir suç tipidir. Ancak, TCK m. 191'de tipikliğin sübjektif unsuru uyuşturucu veya uyarıcı madde imal ve ticaretinden farklıdır. Failin kullanmak maksadiyla hareket etmesi gerekir. Kanun koyucu kasttan önce gelen, kastı hazırlayan bir düşünce olarak kullanma amacını belirleyici bir unsur olarak tipiklikte düzenlemiştir. Başka bir deyişle bu amaç TCK m. 191'de düzenlenen suçun sübjektif haksızlık unsuru olarak tipikliğe dâhildir. Bulunmaması halinde suçun manevi unsuru 191. madde yönünden gerçekleşmez. Şartları varsa TCK m. 188/3'te düzenlenen suç oluşur.

TCK m. 191'de düzenlenen seçimlik hareketler uyuşturucu veya uyarıcı maddenin satın alınması, kabul edilmesi, bulundurulması ve kullanılmasıdır.

155 Körner/Patzak/Volkmer, $\S \S 29$, Rn. 47.

156 “Sanıkların kiralamış oldukları araçla TEM Otoyolunda Akyazı'dan İstanbul istikametine doğru seyir halinde iken ihbar üzerine durdurularak araçta yapılan arama sonucunda ele geçen uyuşturucu madde dişında, sanıkların uyuşturucu maddeyi ticari amaçla naklettiği yolunda bir kanıtın elde edilememesi, Adli Tıp Kurumunun mütalaalarında belirtilen günlük gereksinim miktarı dikkate alındığında, bilirkişi raporunda belirtilen net 393,5 gram uyuşturucu madde miktarının iki kişinin kişisel kullanım sınırları içinde olması, sanıkların tüm aşamalarda araçta bulunan uyuşturucu maddeyi satmak için değil, kullanmak için bulundurdukları yönündeki aksi kanıtlanamayan savunmaları birlikte değerlendirildiğinde, sanıkların uyuşturucu madde ticareti suçunu işlediği kuşku boyutunda kalmaktadır". Yargitay CGK, 16.10.2012, 10-325/1817 UYAP. 
Kullanma dışındaki diğer hareketler TCK m. 188/3'te de yer almaktadır. Bu durumda sübjektif haksızlık unsurundan hareketle hangi suç tipinin ihlal edildiği ortaya konulmalıdır. Manevi unsur kişinin iç dünyası ile alakalı olduğundan failin dış dünyaya yansıyan davranışları ve somut olayın koşulları itibarıyla bu tespitin yapılması gerekir.

Karşılaştırmalı hukukta bazı ülke mevzuatlarında madde miktarı itibarıyla bir sınırlamanın yapıldığı görülmektedir. Belli bir miktarın üzerinde uyuşturucu veya uyarıcı maddeye sahip olunması halinde fiilin ihlal ettiğ $i$ suç tipi veya bu suç için öngörülen yaptırım değişmektedir. Ancak, genel eğilim bu ayrımın yapılmasının soruşturma veya kovuşturma ile görevli makamlara bırakılmasıdır. Hukukumuzda benzer şekilde kanun koyucu eşik miktarlar öngörmemiştir. Kanun koyucu esnek miktarlar yöntemini kabul etmiş ve failin amacının belirlenmesini soruşturma ve kovuşturma ile yetkili ve görevli makamlara bırakmıştır.

Uygulamada her iki suç tipi bakımından Yargıtay bazı ölçütler belirlemiştir. Bu ölçütlere doktrin tarafindan da başvurulmaktadır. Buna göre, öncelikle failin hareketleri ile uyuşturucu veya uyarıcı madde ticaretine yönelik bir davranış içerisine girip girmediğinin tespit edilmesi gerekir. İkinci olarak uyuşturucu veya uyarıcı maddenin bulunduğu yer ve bulundurma şekline dikkat edilmelidir. Failin ekonomik durumu, geçmişinde uyuşturucu veya uyarıcı madde kullanıcısı ya da bağımlısı olup olmadığ 1 değerlendirmeye konu diğer hususlardır. Nihayetinde, madde miktarına failin amacının belirlenmesinde sıklıkla başvurulmaktadır. Yargıtay kararları ile kabul edilen bu hususlar esasen karşılaştırmalı hukukta kabul edilen kriterler ile uyum içerisindedir.

Uygulamada Yargitay kararlarına yansıyan hadiseleri incelediğimizde sıklıkla madde miktarının esas alındığı görülmektedir. Esasen, madde miktarı TCK m. 188 ve 191'de suçun unsuru olarak düzenlenmemiştir. Kanun koyucu belli bir miktar öngörmemiş, türlerine göre miktar bakımından uyuşturucu veya uyarıcı maddeleri sınıflandırmamıştır. Yargıtay da kişisel kullanım için bir sınır miktar belirtmekten kaçınmakta, somut olayın özelliklerine göre diğer kriterler ile birlikte çok yönlü bir biçimde meseleye yaklaşmaktadır. Kimi mahkeme kararlarında sadece madde miktarı veya yakalanan uyuşturucu veya uyarıcı maddenin paket sayısının gözetildiği görülmektedir. Hâlbuki madde miktarı tek başına bir ölçüt değildir. Madde miktarı diğer ölçütlerle birlikte değerlendirilmeli; failin hangi süre ile hangi miktarda kullanmak için uyuşturucu veya uyarıcı madde bulundurabileceği tespit edilmelidir. 
Keza, uygulamada hassas terazi veya tartının uyuşturucu madde ile birlikte yakalandığ 1 ve içeriği tam olarak tespit edilemeyen bir istihbari bilgi ile desteklendiği durumlarda sıklıkla TCK m. 188/3 ile hüküm kurulmaktadır. Oysaki hassas terazi veya tartının bulunduğu her durumdan ticari maksadın varlığı çıkarılamaz. Niteliği itibarıyla bir dozunda bulunması gerekenden fazla maddenin kullanılması halinde ölümcül sonuçların meydana gelmesi mümkündür. Kullanıcı şahıslar, bu tehlikeden kurtulmak amacıyla hassas terazi bulundurabilirler. Bunun gibi uyuşturucu veya uyarıcı maddenin bulundurulduğu veya paketlendiği şeffaf poşetler, bijuteri veya telefon tamiri gibi işlerde kullanılabilir.

Sonuç olarak, kanaatimizce kanun koyucunun eşik miktarlar belirlememesi yerindedir. Nitekim incelenen ülke hukuklarındaki uygulamalar bu kanaatimizi desteklemektedir. Kanun'da buna ilişkin bir hüküm bulunmad1ğından madde miktarı itibarıyla belli kıstaslar saptanması yarardan çok zarar getirebilir. Nitekim failin maksadına bakılmaksızın hareket edilmesi ve otomatik cezalandırma tehlikesi ile karşılaşılabilir. Böyle bir sonuç ceza muhakemesinin temel ilkeleri ile bağdaşmamaktadır. Eşik miktarlara önem verilmesi halinde sanığın suçsuzluğunu ispatlaması, savcılık makamının sadece madde miktarını temel alarak sanığın lehindeki delilleri toplamaması mümkündür. Bu durum aynı zamanda şüpheden sanığın yararlanması, masumiyet karinesi ve maddi gerçeğin araştırılması ilkeleri ile çelişmektedir. 


\section{KAYNAKÇA}

Aksüt, Ertekin: Uyuşturucu veya Uyarıcı Madde İmal ve Ticareti Suçları, Ankara 2020.

Arslan, Çetin: Yargıtay'ın “Uyuşturucu ve Uyarıcı Madde Suçları”na İlişkin Kimi Güncel Kararları ve Bunların Değerlendirilmesi, Uyuşturucu Madde Suçlarına Genel Bakış, Uyuşturucu Madde Bağımlılı̆̆ıyla Mücadele ve Ceza Hukuku, Doğuş Üniversitesi Hukuk Fakültesi Panel (9 Mayıs 2011), Editör: Murat Balc1, Ankara 2011.

Bayraktar, Köksal vd., Özel Ceza Hukuku, Cilt: V, İstanbul 2019.

Bıkmaz, Raif: "Uyuşturucu ve Uyarıcı Madde Ticareti Suçları", Fasikül, Sayı:111, Şubat 2019.

Çetin, Hamza: "Kullanmak İçin Uyuşturucu veya Uyarıcı Madde Satın Almak, Kabul Etmek, Bulundurmak ya da Uyuşturucu veya Uyarıcı Madde Kullanmak Suçu (TCK m. 191), AÜHFD, 65(4) 2016.

EImas, Birsen: Uyuşturucu ve Uyarıcı Madde Suçları, Ankara 4. Baskı, Ankara 2020.

Erman, Sahir/Özek, Çetin: Ceza Hukuku Özel Bölüm, Kamunun Selametine Karşı Suçlar (TCK m. 369-413).

Gökcen, Ahmet: Türk Ceza Kanununda Uyuşturucu Madde Suçlarına Genel Bakış, Uyuşturucu Madde Bağımlılığıyla Mücadele ve Ceza Hukuku, Doğuş Üniversitesi Hukuk Fakültesi Panel (9 Mayıs 2011), Editör: Murat Balc1, Ankara 2011.

Günal, Yılmaz: "Uyuşturucu Madde Kullanma Suçları", Ankara Üniversitesi SBF Dergisi, Cilt: 32, Sayı: 01, Ocak 1977.

Izenman, Alan J.: Sentencing Illicit Drug Traffickers: How Do The Courts Handle Random Sampling Issues?, International Statistical Review, Volume: 71, No: 3 (December 2003).

Kıdıl, Fahrettin: Türk Ceza Hukukunda Uyuşturucu ve Uyarıcı Madde İmal ve Ticareti Suçları, Ankara 2020.

Laursen, Lau/Jepsen, Jorgen: Danish Drug Policy-An Ambivalent Balance between Repression and Welfare, The Annals of the American Academy of Political and Social Science, Vol. 582, Haziran 2002.

Meydan, Uğur: Uyuşturucu Madde Ticareti Suçunda Madde Miktarının Önemi, TAAD, Y11: 10, Say1: 37, Ocak 2019. 
Oğlakçıoğlu, Mustafa Temmuz: Münchener Kommentar zum StGB, 3. Bask1, München 2017.

Öner, Mehmet Zülfü, “Türk Ceza Kanunu'nda Uyuşturucu Madde İmal, İthal ve İhraç Suçları”, TBB Dergisi, Sayı: 88, 2010.

Özbek, Veli Özer/Doğan, Koray/Bacaksız, Pınar: Türk Ceza Hukuku, Özel Hükümler, 15. Bask1, Ankara 2020.

Schäfer, Gerhard/Sander, Günther M./Von Gemmeren, Gerhard: Praxis der Strafzumessung, 6. Bask1, München 2017.

Sevdim, Ali Erdim: Uyuşturucu veya Uyarıcı Madde İmal ve Ticareti Suçu, Ankara 2014.

Soyaslan, Doğan: Ceza Hukuku, Özel Hükümler, 12. Bask1, Ankara 2018.

Tezcan, Durmuş/Erdem, M. Ruhan/Önok, Murat: Teorik ve Pratik Ceza Özel Hukuku, 18. Bask1, Ankara 2020.

Weber, Klaus: Betäubungsmittelgesetz, 5. Bask1, München 2017.

Yaşar, Yusuf: Uyuşturucu ve Uyarıcı Madde İmal ve Ticareti Suçları, 3. Bask1, Ankara 2019.

Yenisey, Feridun: "Uyuşturucu Maddeler Sorunun Ceza Hukuku Yönü”, Dicle Üniversitesi Hukuk Fakültesi Dergisi, Cilt: 1, Sayı: 1, Ekim 1983.

Yokuş Sevük, Handan: Türk Ceza Hukuku, Özel Hükümler, 2. Bask1, Ankara 2019.

Yurtcan, Erdener: Yargıtay Kararları Işığında Uyuşturucu Suçları, 6. Baskı, Ankara 2021.

\section{Elektronik Kaynaklar}

Alexender, Lichtenegger: Die Bedeutung von Mengen für die Strafbarkeit von Verstößen nach dem Suchtmittelgesetz, https://epub.jku.at/ obvulihs/download/pdf/2934194? originalFilename=true erişim tarihi 11.03.2021.

Cannabis Regulation in Europe: Country Report Belgium, Şubat 2019, https://www.tni.org/files/publication-downloads/cr_belgium_082019. pdf erişim tarihi 30.01.2021.

Country Legal Profile: Germany, https://www.emcdda.europa.eu/html.cfm/ index 5174EN.html\# erişim tarihi 30.01.2021.

Country Profile-Austria, https://www.emcdda.europa.eu/html.cfm/index 5174EN.html erişim tarihi 30.01.2021. 
Country Legal Profile: Belgium, https://www.emcdda.europa.eu/html.cfm/ index5174EN.html?pluginMethod=eldd.countryprofiles\& country $=\mathrm{BE}$ erişim tarihi 30.01.2021.

Country Legal Profile: Denmark, https://www.emcdda.europa.eu/html.cfm/ index5174EN.html\# erişim tarihi 02.01.2021.

Country Legal Profile: Italy, https://www.emcdda.europa.eu/html.cfm/ index5174EN.html\# erişim tarihi 02.02.2021.

Country Legal Profile: Spain, https://www.emcdda.europa.eu/html.cfm/ index5174EN.html\# erişim tarihi 02.02.2021.

Country Legal Profile: Sweden, https://www.emcdda.europa.eu/html.cfm/ index5174EN.html\# erişim tarihi 02.02.2021.

Danimarka Ceza Kanunu, https://www.legislationline.org/download/id/6372/ file/Denmark_Criminal_Code_am2005_en.pdf erişim tarihi 01.02.2021.

Drug offences in Italy: conspirancy, dealing and use, https://canestrinilex. com/en/readings/drug-offences-in-italy-detention-and-dealing/ erişim tarihi 30.01.2021.

Drugs in Cyberspace: Understanding \& Investigating Diversion \& Distribution of Controlled Substances via the Internet, http://www.cicad.oas.org/reduccion_oferta/grupoexpertos/Farma_docs/ Drugs_in_Cyberspace_Distribution_Controlled_Substances.pdf erişim tarihi 01.03 .2021 .

Exner, Thomas: Einführung in das Betäubungsmittelstrafrecht, JuS 2019, www.beck-beck.online.de erişim tarihi 15.05.2021.

Gunnar, Cassardt: Zur Feststellung der nicht geringen Menge im Betäubungsmittelstrafrecht, NStZ 1995, www.beck-beck.online.de erişim tarihi 15.05.2021.

Harris, Genevieve: Conviction by Numbers, Threshold Quantities for Drug Policy, Series on Legislative Reform of Drug Policies Nr. 14, http://fileserver.idpc.net/library/Threshold-quantities-for-drugpolicy.pdf, .erişim tarihi 15.05.2021.

Heinrich, Bernd/Van Bergen, Nicolas: Grundzüge des deutschen Betäubungsmittelstrafrechts und seine Entkriminalisierungstendenzen, Juristische Arbeitsblätter, www.beck-online.beck.de erişim tarihi 15.05.2021.

Hughes, Caitlin/Stevens, Alex/Hulme, Shann/Cassidy, Rebecca: Review of approaches taken in Ireland and in other jurisdictions to simple possession drug offences, A report for the Irish Department of Justice 
\& Equality and the Department of Health (and the working group on this issue), Eylül 2018, http://fileserver.idpc.net/library/ANNEXE_I__Hughes_Stevens_Hulme_Cassidy___2018_-_Review_of_approaches_ taken_in_Ireland_and_in_other_jurisdictions_to_simple_possession_dr ug_offences.pdf erişim tarihi 02.02.2021.

İspanya Ceza Kanunu, https://www.legislationline.org/download/id/6443/ file/Spain_CC_am2013_en.pdf erişim tarihi 15.01.2021.

Italy: New drugs law heralds the mass criminalisation of drug users, https://www.statewatch.org/media/documents/news/2004/feb/italynew-drugs-law.pdf erişim tarihi 30.01.2021.

Kirmse, Claudia: Betäubungsmittelstrafrecht - Ein Überblick für Referendare, Juristische Arbeitsblätter, 2011, www.beck-beck.online.de erişim tarihi 15.05.2021.

Körner, Herald Hans/Patzak, Jörn/Volkmer, Mathias: Betäubungmittelgesetz, 9. Bask1, München 2019, erişim için www.beck-online.de erişim tarihi 30.01.2021.

Krumm, Carsten: "Die "nicht geringe menge" im Betäubungsmittelstrafrecht, NJW 2020, 2165, www.beck-online.de erişim tarihi 30.01.2021.

Lai, Gloria: Drugs, Crime and Punishment, Series on Legislative Reform of Drug Policies, Nr. 20, June 2012, http://fileserver.idpc.net/library/ Drugs-crime-and-punishment-Proportionality-of-sentencing\%20(1).pdf erişim tarihi 15.03.2021.

Leipold, Klaus: Das Betäubungsmittelstrafrecht, NJW Spezial, 2004, s. 375 , www.beck-beck.online.de erişim tarihi 15.05.2021.

Moeller, Kim: Enforcement Intensity in Danish Drug Control, 1996-2017, European Journal on Criminal Policy and Research, 2020, http://www.diva-portal.org/smash/get/diva2:1415336/FULLTEXT01. pdf erişim tarihi 02.02.2021.

Nygaard-Christensen, Maj/Vibeke Asmussen, Frank: Cannabis Regulation in Europe: Country Report Denmark, Şubat 2019, https://www.tni.org/files/publication-downloads/cr_denmark 02052019.pdf erişim tarihi 02.02.2021.

Proposal for a COUNCIL FRAMEWORK DECISION laying down minimum provisions on the constituent elements of criminal acts and penalties in the field of illicit drug trafficking, Official Journal 304 E, 
30/10/2001 P. 0172 - 0175, https://eur-lex.europa.eu/legal-content/ EN/TXT/?uri=CELEX\%3A52001PC0259 erişim tarihi 30.01.2021.

Report of the International Narcotics Control Board for 2007, https://www.incb.org/documents/Publications/AnnualReports/AR2007/ AR_07_English.pdf erişim tarihi 15.05.2021.

The role of the quantity in the prosecution of drug offences, European Legal Database on Drugs, https://www.emcdda.europa.eu/system/files/ publications/10503/Quantities.pdf erişim tarihi 30.01.2021.

The EU Action Plan On Drugs (2000-2004), https://www.emcdda.europa.eu/ html.cfm/index1338EN.html erişim tarihi 30.01.2021.

Verordnung der Bundesministerin für Arbeit, Gesundheit und Soziales über die Untergrenzen einer großen Menge (Grenzmengen) bezüglich der Suchtgifte (Suchtgift-Grenzmengenverordnung-SGV), https://www.ris.bka.gv.at/GeltendeFassung.wxe?Abfrage=Bundesnorm en\&Gesetzesnummer $=10011056 \&$ Fassung Vom=2009-06-15 erişim tarihi 30.01.2021.

Zuffa, Grazia: How To Determine Personal Use In Drug Legislation, The "Threshold Controversy" In The Light Of The Italian Experience, Series on Legislative Reform of Drug Policies Nr. 15, https://www.tni.org/files/download/dlr15.pdf erişim tarihi 15. 05.2021.

2013 National Report (2012 data) to the EMCDDA by the Reitox National Focal Point, DENMARK, New development, Trends, and in-depth information on selected issues, https://www.emcdda.europa.eu/system/ files/publications/725/Denmark_NR2012_443264.pdf erişim tarihi 10.03.2021. 
